Portland State University

PDXScholar

Summer 9-12-2019

\title{
Stormwater Treatment Effectiveness of Established Bioretention Facilities in Portland, Oregon
}

\author{
Emma Rose Kohlsmith
}

Portland State University

Follow this and additional works at: https://pdxscholar.library.pdx.edu/open_access_etds

Part of the Water Resource Management Commons

Let us know how access to this document benefits you.

\section{Recommended Citation}

Kohlsmith, Emma Rose, "Stormwater Treatment Effectiveness of Established Bioretention Facilities in Portland, Oregon" (2019). Dissertations and Theses. Paper 5176.

https://doi.org/10.15760/etd.7052

This Thesis is brought to you for free and open access. It has been accepted for inclusion in Dissertations and Theses by an authorized administrator of PDXScholar. Please contact us if we can make this document more accessible: pdxscholar@pdx.edu. 
Stormwater Treatment Effectiveness of Established Bioretention Facilities in Portland, Oregon

by

\title{
Emma Rose Kohlsmith
}

A thesis submitted in partial fulfillment of the requirements for the degree of

\author{
Master of Science \\ in \\ Environmental Science and Management
}

Thesis Committee:

Jennifer Morse, Chair

Eugene Foster

Cara Poor

Portland State University

2019 
(C) 2019 Emma Rose Kohlsmith 


\begin{abstract}
Bioretention systems are commonly used to treat and detain stormwater runoff and help mitigate for many negative effects of urbanization. Despite the widespread use of bioretention systems, few field-based studies have assessed how these facilities affect water quality many years after installation. The goal of this project is to assess the pollution reduction effectiveness of lined bioretention facilities that have been in use and functioning for 4-8 years. To meet this objective, this project measured water quality characteristics of stormwater flowing into and out of seven facilities installed throughout Portland, Oregon during real storm events. Stormwater grab samples were taken over a 2-year period during the fall, winter, and spring. Results showed decreased concentrations of total suspended solids (TSS; 94\%), ammonia (85\%), total copper (59\%), total zinc (80\%), and dissolved zinc (41\%). Results for dissolved copper indicated an overall increase in outflow concentrations of $23 \%$, however variability between facilities was high. These results support other similar findings showing that TSS is effectively reduced by bioretention facilities, even after 4-8 years of use. However, based on this study, effective TSS removal by bioretention facilities does not necessarily equate to equally effective treatment of other pollutants, especially orthophosphate and nitrate, which increased in outflow from the bioretention facilities by $141 \%$ and $2070 \%$, respectively. Results of this study indicate that additional research is necessary to determine the significance of the observed increase in nutrients, understand the underlying mechanisms, and test possible design modifications to improve nitrate and orthophosphate removal.
\end{abstract}




\section{Acknowledgements}

I would like to thank my advisor, Jennifer Morse for her advice and guidance throughout this project, as well as for her patience while I did my best to balance my time between work and school. I would also like to thank Cara Poor for her input with development of this project, as well as her lab (especially Kyla Burrill and Mason Jarvis) for support with processing metals samples. Thank you to Eugene Foster for serving on my committee and providing valuable feedback and insight. Thank you also to many Morse lab members for help with sample analysis.

Numerous people at BES also provided valuable support, guidance and a portion of the data used in this study. Thank you, Adrienne Aiona, for your help developing this project; Jason Law, for endless stats help; Julia Bond, for the many guiding chats; Jordan Lea-James, for sampling advice; and many other SWMM team staff for your thoughts, sharing of ideas and general support. And to my work team for supporting me and putting up with my (sometimes) unpredictable presence at my desk.

Thank you to my family and friends for the never-ending encouragement, support and understanding. And finally, thank you to Stephen for many dinners, endless moral support, providing an often-needed voice of reason, and for sampling with me in the rain for the entirety of Thanksgiving Day.

Funding for this project was provided by the Edward D. and Olive C. Bushby Award. Thank you also to the PSU Center for Lakes and Reservoirs for loaning equipment used in this study. 


\section{Table of Contents}

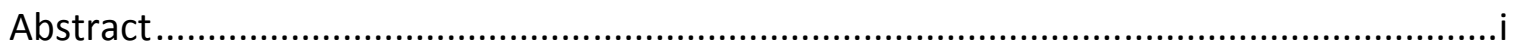

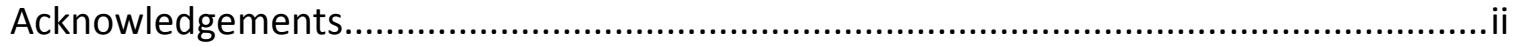

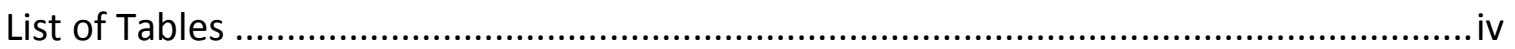

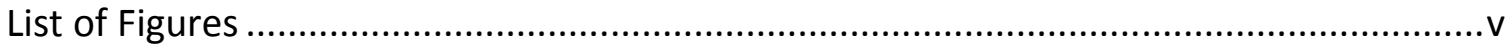

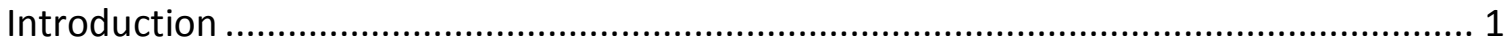

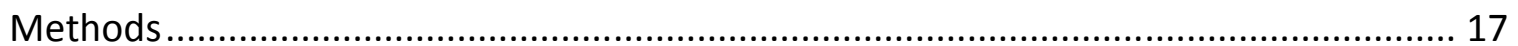

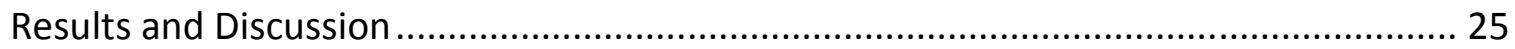

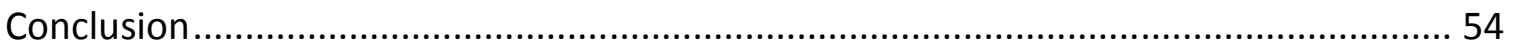

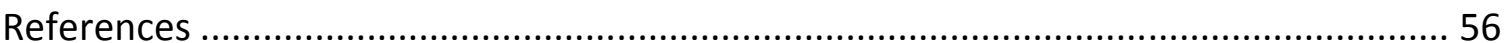




\section{List of Tables}

Table 1: Summary table of study facilities, installation dates and sizing. ...................... 20

Table 2: Number of samples total, per facility, and for each defined season.................. 25

Table 3: Summary table of inflow, outflow and percent reduction for TSS.................. 27

Table 4 Summary table of inflow, outflow and percent reduction for total and dissolved

Zn.

Table 5: Summary table of inflow, outflow and percent reduction for total and dissolved

$\mathrm{Cu}$. 34

Table 6: Summary table of inflow, outflow and percent reduction for orthophosphate and total $P$

Table 7: Summary table of inflow, outflow and percent reduction for ammonia and nitrate.

Table 8: Summary table of inflow, outflow and percent reduction for conductivity, $\mathrm{pH}$ and dissolved oxygen. 


\section{List of Figures}

Figure 1: Simplified general design of monitored bioretention facilities (modified from the City of Portland SWMM Typical Details) ...................................................... 3

Figure 2: Map of facility locations across Portland, Oregon........................................ 19

Figure 3: Typical sample collection methods for inflow (direct sampling or using a stainless-steel shovel) and outflow (using a peristaltic pump)..

Figure 4: Range of TSS values for inflow and outflow for all facilities (A.) and each facility (B.).

Figure 5: Range of total $\mathrm{Zn}$ values for inflow and outflow for all facilities (A.) and each facility (B.).

Figure 6: Range of dissolved Zn values for inflow and outflow for all facilities (A.) and each facility (B.)

Figure 7: Range of total Cu values for inflow and outflow for all facilities (A.) and each facility (B.).

Figure 8: Range of dissolved Cu values for inflow and outflow for all facilities (A.) and each facility (B.)

Figure 9: Photo of facility 14 showing the bioretention facility and the elevated light rail track that drains to it. 36

Figure 10: Range of orthophosphate values for inflow and outflow for all facilities (A.) and each facility (B.).

Figure 11: Range of total phosphorus values for inflow and outflow for all facilities (A.) and each facility (B.).

Figure 12: Range of ammonia values for inflow and outflow for all facilities (A.) and each facility (B.).

Figure 13: Range of nitrate values for inflow and outflow for all facilities (A.) and each facility (B.).

Figure 14: Range of $\mathrm{pH}$ values for inflow and outflow for all facilities (A.) and each facility (B.).

Figure 15: Range of conductivity values for inflow and outflow for all facilities (A.) and each facility (B.).

Figure 16: Range of dissolved oxygen values for inflow and outflow for all facilities (A.) and each facility (B.). 


\section{Introduction}

Land use changes associated with urbanization have significantly altered natural hydrologic regimes, stream habitat, and water quality of receiving water bodies (Coles et al., 2012). Increased impervious surface associated with urbanization reduces the amount of stormwater that can naturally infiltrate into the ground, and this increases the rate and total quantity of stormwater runoff (McGrane, 2016). These impacts have led to altered urban hydrologic regimes, which have negatively affected downstream receiving water bodies by causing increased flashiness, flooding, and erosion (Coles et al., 2012; Paul and Meyer, 2001). In addition, urbanization has led to an increase in pollutant export: water running over polluted impervious surfaces (such as roads, roofs, or parking lots) picks up pollutants and transports them into groundwater, and/or to rivers, estuaries, and the ocean (McGrane, 2016; Paul and Meyer, 2001). These pollutants can include nutrients, metals, bacteria, pesticides, and sediment. The combination of increased pollutant loads and altered hydrology due to urbanization has numerous negative impacts on ecosystems, fish, invertebrates and biogeochemical cycles (McGrane, 2016; Paul and Meyer, 2001; Walsh et al., 2005).

In response to these hydrologic and water quality impacts and to meet associated regulatory requirements, stormwater managers have implemented various strategies for managing stormwater runoff (Barbosa et al., 2012). Stormwater management systems are often designed to either mimic pre-development conditions by allowing runoff to infiltrate into the ground (as would have occurred prior to 
development), or mitigate for downstream impacts by slowing and treating water prior to discharge to surface waters or combined sewers (Bonneau et al., 2017). The specific design and type of stormwater management system utilized for a development often varies based on geologic conditions, local regulations, existing infrastructure, and receiving water bodies (Walsh et al., 2016).

In Portland, OR, municipal stormwater management regulations require that stormwater be infiltrated into the ground on each site, to the maximum extent feasible (Bureau of Environmental Services, 2016). Infiltration feasibility is based on soil percolation rates, slope stability, and other site constraints. When feasible, stormwater will be infiltrated into the ground using pervious paving, underground injection systems (such as drywells or soakage trenches), vegetated infiltration basins, or rain gardens. Where soil conditions are unsuitable for infiltration or site constraints limit infiltration near slopes or structures, other stormwater facilities are required to reduce pollutants in stormwater runoff and slow runoff prior to discharge to storm sewers, combined sewers, or rivers. Under these circumstances, common stormwater management strategies in Portland include bioretention facilities, ecoroofs, manufactured treatment systems, and underground detention systems.

This study focuses on lined bioretention facilities, which are very commonly used in Portland to treat and detain stormwater runoff. Lined bioretention facilities filter stormwater through amended soil media consisting of a combination of loamy soil, sand, and compost. The facilities are vegetated, and a layer of gravel containing an 
underdrain is located below the soil media to collect and convey treated stormwater out of the facility and into the receiving system (Figure 1). Lined bioretention facilities are installed to reduce pollution in runoff and to mitigate the effects of altered hydrologic regimes prior to discharge to the receiving system (either a storm-only sewer or a combined sewer system). Although hydrologic performance of these facilities is equally important and in need of additional assessment, the focus of this study is on the pollution reduction effectiveness of lined bioretention facilities as implemented in Portland, Oregon.

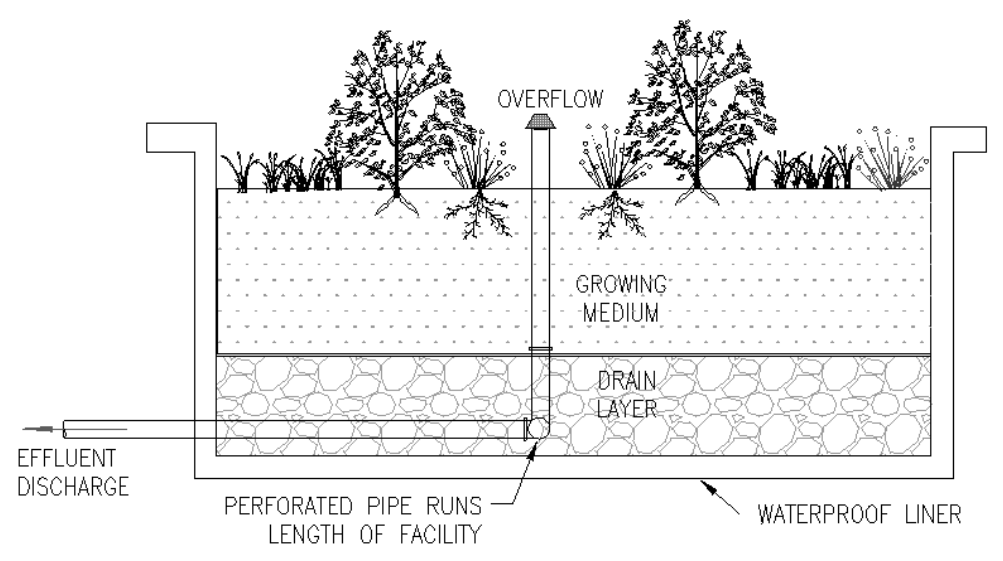

Figure 1: Simplified general design of monitored bioretention facilities (modified from the City of Portland SWMM Typical Details).

Vegetated stormwater facilities improve water quality by retaining and removing pollutants through multiple complex and interconnected processes including settling, filtration, sorption, precipitation, biodegradation, plant uptake, nitrification, denitrification, and volatilization (Clar et al., 2004). These processes are discussed in additional detail for specific pollutants below. In general, studies have shown consistent and effective removal of total suspended solids (TSS) by bioretention facilities, often in 
the range of 90\% reduction (Bratieres et al., 2008; Hatt et al., 2009; Hsieh and Davis, 2005). However, results for other pollutants have been much less consistent. Results for metals, including copper $(\mathrm{Cu})$ and zinc $(\mathrm{Zn})$ from bioretention systems have been variable, with some observed leaching of Cu especially in new facilities (Chahal et al., 2016; Herrera Environmental Consultants, Inc., 2014; Mullane et al., 2015; Trowsdale and Simcock, 2011). Studies have documented lower effectiveness in removing phosphorus $(\mathrm{P})$ and nitrogen $(\mathrm{N})$ and, in some cases, export of these nutrients from the facilities (Chahal et al., 2016; Davis et al., 2006, 2001b; Hatt et al., 2009; Herrera Environmental Consultants, Inc., 2014; Hsieh and Davis, 2005; Mullane et al., 2015). Increased levels of P from bioretention facilities is often attributed to leaching from organic matter and soil media (LeFevre et al., 2015). $\mathrm{N}$ is primarily leached as nitrate and attributed to $\mathrm{N}$ cycling within the facility (Davis et al., 2006; Kim et al., 2003; LeFevre et al., 2015; Yang and Lusk, 2018).

Many bioretention treatment studies, including many cited above, attempt to mimic field conditions using lab-based mesocosm studies and synthetic stormwater. Although lab-based studies are very efficient, convenient, and useful for separating and evaluating the interrelated processes occurring within bioretention systems, they are nonetheless simplified systems that may not accurately reflect the field performance of established facilities (Liu et al., 2014). Lab-based studies are generally initiated and completed within a few months or years and, therefore, may not accurately represent how a facility will function many years after installation. In addition, plants may not be 
fully established in the mesocosms, fungi and mycorrhizae may not be fully present, and pollutant accumulation that may occur after many years of use may not be accurately represented.

Given the observed variability in treatment effectiveness and general lack of field-based studies, it is necessary to assess the functioning of Portland's typical lined bioretention stormwater facilities. Although field-based studies introduce variability that cannot be easily controlled, results likely provide a more accurate representation of effectiveness, especially many years after installation.

\section{$\underline{\text { Regulatory Nexus }}$}

Determining the effectiveness of bioretention facilities in Portland also has important regulatory drivers. Portland is served by a system that consists of combined sewers (stormwater and sanitary flows are discharged into the same system) and separated storm and sanitary sewers. Each system has unique regulatory drivers, which influence stormwater management requirements. For the combined sewer system, emphasis is placed on reducing the total quantity of stormwater discharged into the system and providing flow control to slow stormwater that is discharged into the system. These requirements for the combined sewer system help mitigate for the inadequate capacity of the combined sewer system and the wastewater treatment plant during large storms, and ultimately help reduce combined sewer overflows to local waterways. For the municipal separate storm sewer system (MS4), in addition to slowing and reducing total flows, additional emphasis is placed on removal of pollutants 
to reduce the load discharged into downstream water bodies. Stormwater discharges to the MS4 system are regulated through the National Pollutant Discharge Elimination System (NPDES) MS4 permit.

The City of Portland (COP) received approval of its first Phase I NPDES MS4 Discharge Permit in 1995. The permit was renewed in 2004 and 2011 and has been administratively extended by the Oregon Department of Environmental Quality (DEQ) since 2016 (City of Portland and Port of Portland, 2018). A key component of the COP NPDES permit is the Stormwater Management Plan (SWMP), which describes specific measures the City will take to reduce pollutants discharged to receiving waterbodies, including implementing post-construction stormwater pollutant and runoff control programs (OR DEQ, 2011). Bioretention facilities are one of the most common types of stormwater management infrastructure installed in Portland to meet post-construction stormwater management obligations, therefore understanding their treatment effectiveness is essential.

A second key component of the approved COP NPDES permit is a monitoring program designed to assess the effectiveness of the Stormwater Management Plan in reducing pollutant discharge to the MS4 system. As a component of this monitoring, the COP Bureau of Environmental Services (BES) designed a study to determine the water quality effectiveness of lined bioretention facilities. The results presented here consist of a combination of water quality data collected by BES, as well as samples collected by me. Stormwater samples were analyzed for nitrogen (in the form of ammonia and 
nitrate), orthophosphate, total $\mathrm{P}$, total and dissolved $\mathrm{Zn}$, total and dissolved $\mathrm{Cu}$, and general water quality parameters including TSS, $\mathrm{pH}$, dissolved oxygen, and conductivity. Total Suspended Solids

High contributions of suspended sediment in stormwater runoff can have numerous negative impacts on downstream receiving water bodies. Increased suspended sediment in the water column can lead to worsened turbidity, which reduces the ability of light to penetrate through the water column and can impact the growth of beneficial aquatic vegetation (US EPA, 1999). Suspended sediment can also directly impact sensitive fish species through impaired oxygen transfer due to sediment accumulation on gills, immune system disruption and impacts to feeding due to reduced light availability (Capper, 2006; Kjelland et al., 2015). Increased settling of suspended solids onto the beds of receiving waterbodies can lead to alteration and destruction of key habitat for fish and other bottom-dwelling organisms (US EPA, 1999). Finally, many other contaminants bind to suspended solids, therefore increased suspended sediments are often correlated with increased loads of contaminants such as metals and hydrophobic organic chemicals (Roy-Poirier et al., 2010a; Schoellhamer et al., 2007). The primary sources of suspended sediment in urban stormwater runoff include vehicle exhaust emissions, tire wear, brake wear, construction site erosion, road paint, atmospheric deposition, agricultural runoff, and organic sources such as soil material and plant debris (Taylor and Owens, 2009). 
Research and monitoring has generally shown that, with the exception of an initial flushing period, bioretention facilities are effective at reducing TSS in stormwater effluent (Davis et al., 2009; Liu et al., 2014; Roy-Poirier et al., 2010a). The primary mechanisms by which suspended sediments are removed in bioretention facilities are sedimentation and filtration (Davis et al., 2009; Liu et al., 2014). Clogging of bioretention facilities and reduced hydraulic conductivity have been observed and acknowledged as potential issues arising from suspended sediment removal in bioretention facilities (RoyPoirier et al., 2010a).

The COP Stormwater Management Manual (SWMM) describes TSS as a surrogate measure for water quality and states that percent removal of TSS is an accepted measure of overall pollution reduction (Bureau of Environmental Services, 2016). However, this assumption likely does not account for dissolved pollutants. The results of this study will help test the correlation between TSS and overall pollution reduction in bioretention facilities and inform future policy.

$\underline{\text { Zinc }}$

$\mathrm{Zn}$ is a naturally occurring component of Earth's crust and an essential trace element for life. However, at high concentrations, Zn can be toxic to plants and aquatic species (US EPA, 1980). In aquatic environments, Zn toxicity is primarily caused by free $\mathrm{Zn}^{2+}$ ions, the level of which is controlled by levels of dissolved organic matter, calcium, and $\mathrm{pH}$ of the water (Hogstrand, 2011). Elevated levels of $\mathrm{Zn}$ in aquatic environments have been shown to be toxic to benthic macroinvertebrates and fish, with toxicity 
varying based on $\mathrm{pH}$ and other water quality parameters (Brinkman and Johnston, 2007; Cusimano et al., 1986; Mebane et al., 2012). Acute toxicity in fish is generally attributed to inhibition of calcium uptake due to competition for ion uptake, resulting in hypocalcaemia and fish death (McRae et al., 2016). Acute $\mathrm{Zn}$ toxicity can also cause coagulation of mucus on the gills, which can impact ion regulation as well as impair oxygen exchange at the gills, causing hypoxia (Burton et al., 1972; McRae et al., 2016). The sublethal effects of $\mathrm{Zn}$ are less well understood and appear to be a current research interest and need (Rostern, 2017).

$\mathrm{Zn}$ is released into the environment from both natural and anthropogenic sources but cycling is significantly increased through anthropogenic causes, with an estimated anthropogenic enrichment factor of $72 \%$ (Walker et al., 2012). In urban stormwater runoff, common Zn sources include tire wear, wet and dry deposition, roof and building siding materials, brake wear, and industrial or manufacturing activities (Davis et al., 2001a; LeFevre et al., 2015).

In bioretention systems, a portion of $\mathrm{Zn}$ removal in effluent is accomplished through filtration of suspended sediments containing particulate Zn (LeFevre et al., 2015). Dissolved Zn can be taken up in sediments or suspended solids through sorption (LeFevre et al., 2015). The amount of $\mathrm{Zn}$ sorbed to soil depends on plant uptake, losses by leaching, changes in soil moisture, changes in $\mathrm{pH}$, mineralization of organic matter, interactions with other metals, and changes in the redox potential of the soil (WHO, 2001). Multiple studies have documented the important role of mulch and compost in 
bioretention systems to increase sorption of metals (Davis et al., 2001b; Jang et al., 2005; Paus et al., 2014). However, it is important to note that metals sorbed within the bioretention media are not permanently sequestered and can still leach out of the facility (LeFevre et al., 2015). The final process by which metals can be removed within bioretention systems is through plant uptake and biomass harvest. However, plant species vary widely in their ability to take up metals and some studies have observed very limited effectiveness of plant metal uptake (LeFevre et al., 2015; Read et al., 2008).

\section{Copper}

Similar to $\mathrm{Zn}, \mathrm{Cu}$ is an essential trace element that can become toxic at higher concentrations (Grosell, 2011; Sandahl et al., 2007; Solomon, 2009). In fish, exposure to high levels of Cu can damage gills and impair the organism's ability to regulate salts, which can result in death (Solomon, 2009). Other studies have shown that Cu exposure can negatively affect a fish's olfactory system, which can have a significant impact on its ability to locate food, avoid predators, reproduce, and migrate, all of which may threaten its ability to survive (Baldwin et al., 2003; Solomon, 2009). Aquatic invertebrates are also sensitive to $\mathrm{Cu}$; exposure to $\mathrm{Cu}$ has been shown to reduce the total number and diversity of macroinvertebrate species and skew diversity towards less sensitive species (Clements et al., 1988; Solomon, 2009). Cu has been used as an algicide; it is toxic to algae and plants and is known to impair various key processes including photosynthesis, respiration, cell division, and enzyme activity (Scannell, 2009; Solomon, 2009). 
The toxicity of $\mathrm{Cu}$ to aquatic species varies significantly based on water chemistry (Santore et al., 2001). The biotic ligand model (BLM) for Cu was developed in order to improve the accuracy of calculated $\mathrm{Cu}$ water quality criteria by taking into account related water chemistry parameters. The BLM accounts for variation in $\mathrm{pH}$, calcium, magnesium, sodium, potassium, chloride and sulfate levels, organic matter content, alkalinity, and temperature (US EPA, 2016).

$\mathrm{Cu}$ in urban stormwater runoff is primarily attributed to vehicle exhaust, brake pad wear, roofing and flashing materials, treated wood, and pesticide applications (Sandahl et al., 2007). In stormwater and in aquatic environments, $\mathrm{Cu}$ is present in both particulate and dissolved forms, but toxicity is primarily attributed to dissolved $\mathrm{Cu}^{2+}$ ions (Nason et al., 2012). Mechanisms of Cu removal in bioretention facilities include filtration, sorption, and plant uptake (LeFevre et al., 2015). These removal mechanisms are analogous to those described in additional detail for Zn (above). However, competition for sorption sites can occur between $\mathrm{Cu}$ and $\mathrm{Zn}$; observations generally show that $\mathrm{Cu}$ has a higher affinity for sorption sites and may outcompete $\mathrm{Zn}$, potentially causing Zn to be released (Elliott et al., 1986; Morgan et al., 2011).

\section{Phosphorus}

$P$ is an essential nutrient for living organisms and is often the nutrient that limits excess algal growth and eutrophication in most freshwater and some saltwater systems (Rosenquist et al., 2010). Increased release of $\mathrm{P}$ in stormwater runoff can impact downstream biogeochemical cycling and cause numerous problems for downstream 
water bodies including eutrophication, toxic algal blooms, hypoxia, loss of biodiversity, and impairment of water for use (such as for drinking water, recreation, agriculture, and other uses) (Carpenter et al., 1998; Hsieh et al., 2007a; Rosenquist et al., 2010). The primary sources of $P$ in urban stormwater runoff include soil erosion, fertilizers, plant detritus, detergents, pet waste, and atmospheric deposition (Carpenter et al., 1998; Hsieh et al., 2007a; Janke et al., 2014; Yang and Lusk, 2018). The P cycle is primarily driven by geochemical processes. $\mathrm{P}$ in stormwater runoff is present in both dissolved (as organic $\mathrm{P}$ and orthophosphate, $\mathrm{PO}_{4}{ }^{3-}$ ) and particulate forms (Hsieh et al., 2007a; Li and Davis, 2016; Yang and Lusk, 2018). Due to its increased bioavailability, orthophosphate is of higher concern for discharge into receiving waterbodies (Correll, 1998).

Mechanisms for P removal in bioretention systems differ for particulate versus dissolved forms (Li and Davis, 2016). The primary mechanism for removal of particulate $\mathrm{P}$ in bioretention systems is through sediment removal (sedimentation and filtration). Numerous studies have shown that bioretention facilities effectively reduce suspended sediment in runoff, which therefore traps and reduces exported particulate-bound $\mathrm{P}$ (Hunt et al., 2012). The primary mechanisms of dissolved $\mathrm{P}$ removal in bioretention facilities are sorption and precipitation (Hunt et al., 2012; Li and Davis, 2016; Liu and Davis, 2014; Roy-Poirier et al., 2010b). The removal of $P$ through sorption and precipitation is highly dependent on many variables, including facility design, soil characteristics, and environmental factors, such as the P content of the soil media, amount of organic matter, $\mathrm{pH}$, presence of amorphous iron, aluminum and calcium 
levels in soils, media infiltration rates, and oxygen availability (Hunt et al., 2012; Li and Davis, 2016; Minton, 2005). In addition, sorption capacity can decrease with increased history of $\mathrm{P}$ exposure, eventually leading to reduced removal effectiveness and potential breakthrough (Li and Davis, 2016). Mineralization, immobilization (accumulation of nutrients in soil microbes) and vegetative uptake also contribute to P cycling in bioretention facilities; however, the significance of their contribution to P removal in effluent is less well understood (Roy-Poirier et al., 2010b).

Improving P removal capacity of bioretention facilities is a current and active area of research. Some potential amendments to improve P sorption and precipitation include water treatment residuals (Liu and Davis, 2014; Lucas and Greenway, 2011; O'Neill and Davis, 2012; Poor et al., 2018), iron amendments such as shavings and steel wool (Erickson et al., 2007), and fly ash (Zhang et al., 2008). None of these amendments were utilized in the facilities monitored for this study.

\section{Nitrogen}

Elevated levels of $\mathrm{N}$ in stormwater runoff can impact downstream biogeochemical cycling and lead to many of the same negative impacts described above for P (Carpenter et al., 1998; Collins et al., 2010; Compton et al., 2011). Anthropogenic sources of $\mathrm{N}$ in stormwater runoff include chemical fertilizers, leaking wastewater infrastructure, pet waste, atmospheric deposition, and deposition from combustion (Bettez and Groffman, 2013; Collins et al., 2010; Law et al., 2004; Yang and Toor, 2016). Multiple studies have documented increased $\mathrm{N}$ deposition from vehicle combustion 
along roadways and in urban areas, resulting in increased $\mathrm{N}$ in stormwater runoff (Collins et al., 2010; Davidson et al., 2010).

$\mathrm{N}$ in stormwater can be both dissolved and particulate; however, dissolved $\mathrm{N}$ is of additional concern due to its increased bioavailability to simple organisms. Dissolved forms of $\mathrm{N}$ in stormwater include nitrate $\left(\mathrm{NO}_{3}{ }^{-}\right)$, nitrite $\left(\mathrm{NO}_{2}{ }^{-}\right)$, ammonia and ammonium $\left(\mathrm{NH}_{3}\right.$ and $\mathrm{NH}_{4}^{+}$) and organic $\mathrm{N}$ (LeFevre et al., 2015). Bioretention facilities can alter both the form and the total amount of $\mathrm{N}$ in stormwater runoff through multiple interrelated processes; ammonification and nitrification change the form of $\mathrm{N}$ present while assimilation, denitrification, and adsorption reduce the total amount of $\mathrm{N}$ in stormwater (Collins et al., 2010). Ammonification is the process by which microorganisms break down organic $\mathrm{N}$ to release $\mathrm{NH}_{4}^{+}$; it is often called $\mathrm{N}$ mineralization and can occur in both aerobic and anerobic conditions (Hopkinson and Giblin, 2008; Schlesinger and Bernhardt, 2013). Following ammonification and generally under aerobic conditions, nitrifying bacteria and archaea further transform ammonia into $\mathrm{NO}_{2}{ }^{-}$and $\mathrm{NO}_{3}{ }^{-}$(Collins et al., 2010). $\mathrm{N}$ can be removed from stormwater effluent through three processes: assimilation, adsorption, and denitrification (Collins et al., 2010; Hunt et al., 2012). Through assimilation, inorganic $\mathrm{N}\left(\mathrm{NH}_{4}{ }^{+}, \mathrm{NO}_{2}{ }^{-}\right.$, and $\left.\mathrm{NO}_{3}{ }^{-}\right)$can be temporarily transformed into organic $\mathrm{N}$ as it becomes incorporated into microbial or plant biomass (Collins et al., 2010). Adsorption also temporarily removes $\mathrm{N}$ through $\mathrm{NH}_{4}{ }^{+}$adsorbing on to negatively charged soil particles (Collins et al., 2010). Denitrification permanently removes N through the transformation of nitrate or nitrite to gaseous $\mathrm{N}$ in the form of nitrous oxide 
$\left(\mathrm{N}_{2} \mathrm{O}\right)$ or dinitrogen $\left(\mathrm{N}_{2}\right)$, which is released to the atmosphere; it occurs under anaerobic conditions (Hsieh et al., 2007b; Hunt et al., 2012).

\section{General Water Quality Parameters}

Field-measured water quality parameters such as $\mathrm{pH}$, conductivity, and dissolved oxygen can function as indicator parameters for general water quality degradation. In addition, poor levels of these parameters can have direct impacts on aquatic fauna in receiving waterbodies (Azrina et al., 2006; Courtney and Clements, 1998). Changes in pH can also impact N and P cycling and sorption (Li and Davis, 2016; Minton, 2005) as well as metal speciation (separation between the dissolved and particulate forms) in aquatic environments (Minton, 2005). Levels of dissolved oxygen can play an important role in nutrient cycling and metal solubility. For $\mathrm{N}$, low dissolved oxygen is necessary for removal of nitrate through denitrification, but higher levels are necessary for nitrification. In addition, changes in dissolved oxygen levels can impact sorption and desorption of phosphorus and metals (Minton, 2005).

\section{$\underline{\text { Variability between Seasons }}$}

Inflow pollutant levels are expected to be higher in the fall due to increased leaf and plant debris inputs, longer dry periods between storms, and first flush effects following Portland's generally dry summers. In addition to leaf litter, pollen can also contribute additional $\mathrm{N}$ and $\mathrm{P}$ in runoff, resulting in increased levels in the spring (Brown et al., 2013). Seasons may also impact bioretention treatment effectiveness for some analytes, primarily due to changes in temperature. A biofilter column study showed no 
effect of temperature on treatment effectiveness for TSS and total P; however, nitrogen treatment effectiveness was impacted. Specifically, lower temperatures decreased nitrification rates, ammonia removal efficiency was better at higher temperatures, and higher temperatures led to increased leaching of nitrate (Blecken et al., 2010). Similarly, a field-study in Nashville, NC, showed increased export of nitrate during warmer months and attributed the trend to increased microbial activity (Brown et al., 2013).

Available literature is limited regarding potential effects of seasonality and temperature on metal removal in bioretention facilities. One study showed no effect of season on mass removal of $\mathrm{Zn}$ but showed a decrease in removal efficiency of $\mathrm{Cu}$ in spring compared to summer; however, the mechanism was unclear (Muthanna et al., 2007).

Plant uptake of nutrients and metals may also vary by season due to variability in plant growth rates. However, the overall contribution of plant uptake in pollutant removal is unclear. Two studies have documented metal uptake by plants of between $0.5 \%$ and $7 \%$ of the total retained by the facilities (Muthanna et al., 2007; Sun and Davis, 2007). Nutrient uptake by plants has been shown to contribute to overall removal; however, the significance of the contribution can be highly variable (Read et al., 2008).

\section{$\underline{\text { Study Objectives }}$}

The overall goal of this project is to accurately assess the pollution reduction effectiveness of lined, bioretention stormwater facilities that have been in use and functioning for many years. To meet this objective, this project measured water quality 
of stormwater flowing into and out of multiple facilities installed throughout Portland during real storm events. The seven stormwater facilities used for this study have been in use for 4-8 years and are past their initial establishment period. Stormwater grab samples were taken throughout multiple water years and at various times throughout the season. The study aims to answer the following research questions:

1. Are established lined bioretention facilities effectively reducing the concentration of nutrients $(\mathrm{N}$ and $\mathrm{P}$ ) in stormwater runoff?

2. Are established lined bioretention facilities effectively reducing the concentration of metals ( $\mathrm{Cu}$ and $\mathrm{Zn}$ ) in stormwater runoff?

3. How are lined bioretention facilities impacting general water quality parameters (total suspended solids, conductivity, $\mathrm{pH}$, and dissolved oxygen)?

4. Does water quality or treatment effectiveness vary between seasons?

\section{Methods}

\section{$\underline{\text { Study Sites }}$}

To assess the pollution reduction effectiveness of established, lined, bioretention facilities, seven facilities were selected throughout Portland, Oregon (Figure 2). Facilities were initially randomly selected from a list of facilities greater than 4 years old. However, initial sampling efforts of the facilities were not successful due to challenges with inlet and underdrain design (which did not allow for sampling using the methods proposed), or issues with facilities having too little flow during storm events. Therefore, 
facilities were ultimately selected based on ability to collect samples and were not selected randomly.

All of the facilities were installed between 2010 and 2014 and, at the time of sampling, had been in use for a minimum of 3.5 years and a maximum of 8 years. The sampled facilities are all fully lined and are not intended to infiltrate stormwater into subgrade soils. They vary in their specific size and shape, but all facilities were installed using a standard soil blend installed above a layer of drain rock, as shown in Figure 1. The soil blend is intended to slow and filter water prior to discharge and to support vegetation growing in the facilities. An underdrain pipe is located at the bottom of the drain rock to collect treated stormwater and discharge it to the receiving system (a storm-only or combined sewer pipe). All facilities are planted, but with varying vegetation health, coverage, and species. The variability in vegetation characteristics was not assessed as a part of this study and may be an uncontrolled variable impacting differences in effectiveness between facilities. All facilities were sized to meet either the COP pollution reductions requirements, or to meet both pollution reduction and flow control requirements as defined in the COP Stormwater Management Manual (BES, 2016). All facilities were installed using the current COP soil blend, which was established in 2010 (therefore no facilities installed prior to this date were used in this study). This soil blend contains loamy soil, sand and compost, with a requirement for $30-$ $40 \%$ compost by volume (City of Portland, 2019). 


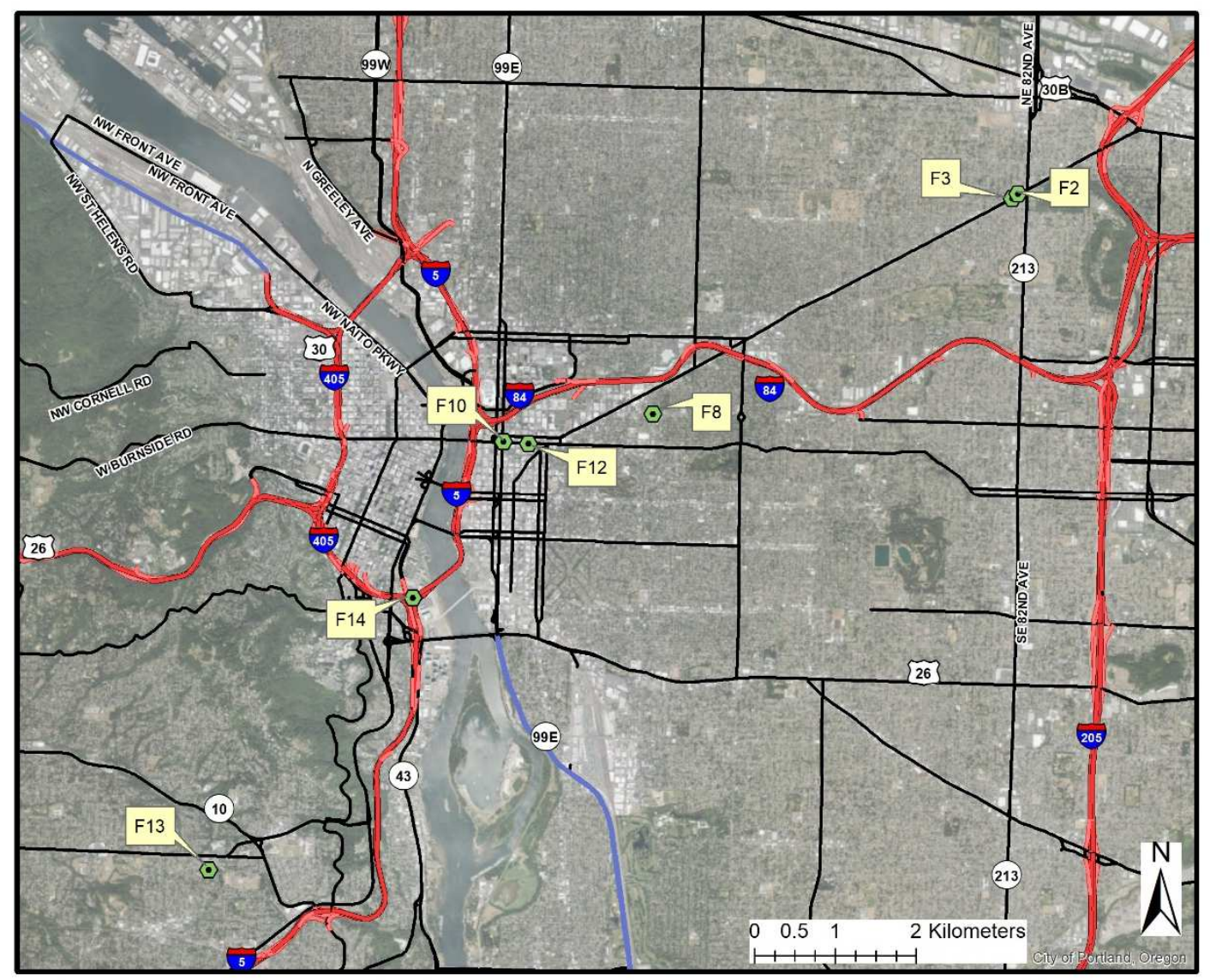

Figure 2: Map of facility locations across Portland, Oregon.

All sampled facilities manage surface runoff from the public right-of-way.

However, the specific catchment areas vary in use and intensity: one facility receives runoff from a residential local service street; another receives runoff from an elevated light-rail track; and the remaining five facilities manage runoff from high classification, high use streets (designated by the COP as major City Traffic Streets). Catchment areas range in size from 446 square meters to 4,634 square meters. Facility sizes range from 8.5 square meters to 75.3 square meters, and specific sizing ratios of the facility area to the drainage basin area range from $1.6 \%$ to $6.6 \%$ (Table 1 ). 
Table 1: Summary table of study facilities, installation dates and sizing.

\begin{tabular}{cccccc}
\hline Facility & Nearest Address & $\begin{array}{c}\text { Date } \\
\text { Installed }\end{array}$ & $\begin{array}{c}\text { Drainage Basin Area } \\
\left(\mathbf{m}^{\mathbf{2}} \mathbf{c}\right.\end{array}$ & $\begin{array}{c}\text { Facility Area } \\
\left(\mathbf{m}^{\mathbf{2}}\right)\end{array}$ & $\begin{array}{c}\text { Sizing Ratio } \\
(\mathbf{\%})\end{array}$ \\
\hline F2 & 8025 NE Sandy Blvd & Aug 2012 & 446 & 8.5 & 1.9 \\
F3 & 7930 NE Sandy Blvd & Aug 2012 & 1,076 & 20.3 & 1.9 \\
F8 & 2807 NE Glisan St & Jan 2011 & 669 & 15.8 & 2.4 \\
F10 & 515 E Burnside & Dec 2010 & 782 & 17.3 & 2.2 \\
F12 & 1000 E Burnside & Dec 2010 & 844 & 16.1 & 1.9 \\
F13 & 2750 SW California St & Jul 2014 & 480 & 31.9 & 6.6 \\
F14 & SW Moody \& Sheridan & Apr 2014 & 4,634 & 75.3 & 1.6
\end{tabular}

\section{Field Sampling}

In order to quantify the impact of the facility on water quality parameters, water samples were collected pre- and post-treatment during storm events. Sampling began during the 2016-2017 water year and concluded at the end of the 2018-2019 water year. The same seven facilities were sampled following the same sampling methods by both BES and myself.

Samples were generally collected with an antecedent dry period of at least 6 hours. However, due to the difficulty and unpredictability of storm sampling, this condition may not have been precisely met for all samples. BES began sample collection in May 2017 and continued collecting samples intermittently until Spring 2019. My research samples were collected throughout the 2018-2019 water year.

Stormwater runoff flowing into the facility was collected at the facility inlet by placing bottles directly into the line of flow or by scooping sheet flow into bottles using a clean stainless-steel flat shovel. Treated effluent was pumped from the facility underdrain with access through a beehive overflow structure or downstream catch 
basin. Effluent samples were pumped into bottles using a peristaltic pump with a new segment of clean silicone tubing for each sampling location. Samples were not collected if the facility was overflowing since the untreated stormwater would contaminate the treated underdrain flow. Samples for metal analysis were collected into nitric acidwashed bottles. Samples for nutrient analysis and TSS were collected into phosphatefree detergent and water washed bottles (not acid-washed). Samples for nutrient analysis and dissolved metals were filtered in the field immediately after collection using $0.45 \mu \mathrm{m}$ PES membrane syringe filters. General water quality parameters $(\mathrm{pH}$, temperature, conductivity, and dissolved oxygen) were measured immediately following collection using a YSI 556 Handheld Multiparameter Instrument or In-Situ SmarTROLL Multiparameter meter. Samples were placed in a cooler immediately following collection and then refrigerated until analysis. Samples analyzed at PSU were measured within 7 days of collection. Samples analyzed by BES were measured within 7 days for TSS, 48 hours for nitrate and orthophosphate, 28 days for ammonia (acid-preserved), and usually 2 weeks but up to 6 months for metals (acid-preserved). 

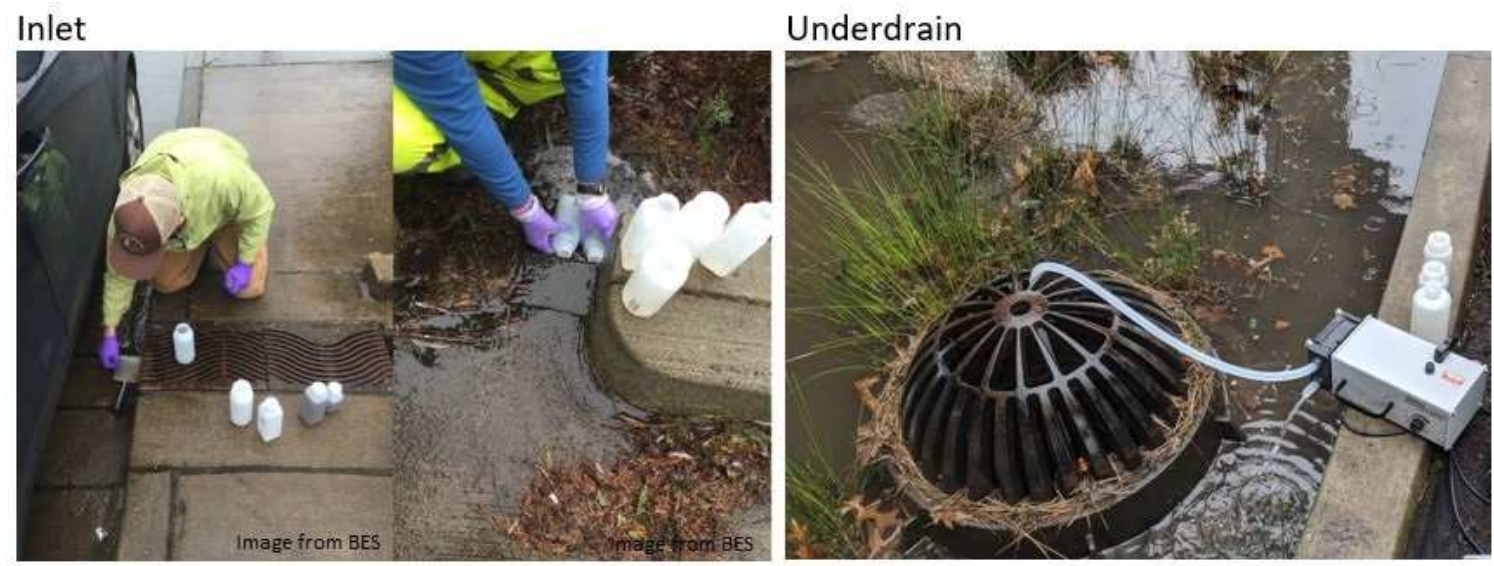

Figure 3: Typical sample collection methods for inflow (direct sampling or using a stainless-steel shovel) and outflow (using a peristaltic pump). Inlet photos from BES.

\section{Laboratory Analysis}

Nutrient analysis at PSU was completed using a Smartchem 170 colorimetric discrete analyzer (Unity Scientific, Milford, MA). Nitrate plus nitrite was measured using EPA Method 353.2 Revision 2.0 (US EPA, 1993a), ammonia was measured using Standard Methods 4500-N org -D, and orthophosphate was measured using Standard Method 4500-P.F (American Public Health Association, 2005). Samples collected by PSU for metals analysis were measured for total and dissolved $\mathrm{Cu}$ and total $\mathrm{Zn}$ using an AA7000 atomic absorption spectrophotometer (Shimadzu, Kyoto, Japan). However, those results are not included in the following analysis due to apparent contamination of filtered samples and concerns with accuracy of the measurements.

Samples collected by BES were analyzed using different processes and equipment. Nitrate was measured using a 930 Compact IC Flex ion chromatograph (Metrohm, Herisau, Switzerland) following EPA Reference Method 300.0 (US EPA, 1993b). Ammonia and orthophosphate were measured using an Astoria2 automated 
segmented flow analyzer (Astoria Pacific, Clackamas, Oregon) following EPA Reference Methods 350.1 (US EPA, 1993c) and 365.1 (US EPA, 1993d), respectively. Total P and total and dissolved $\mathrm{Cu}$ and $\mathrm{Zn}$ were measured by BES using an ICAP-Q inductively coupled plasma mass spectrometer (Thermo Scientific, Waltham, MA) following EPA Reference Method 200.8 revision 5.4 (US EPA, 1994).

Total suspended solids (TSS) was analyzed in both laboratories using Standard Methods 2510 D, Total Suspended Solids Dried at 103-105 ${ }^{\circ} \mathrm{C}$ (American Public Health Association, 2005).

Due to the location of the facilities along streets and facility configurations, it was not feasible to monitor total flow rate and volume for this study. Therefore, reported values are for grab sample concentrations and do not represent changes in pollutant mass loading.

\section{$\underline{\text { Statistical Analysis }}$}

Due to the repeated measurements for each of the seven facilities, this dataset has a hierarchical structure, and individual observations within each facility are not considered independent. It is likely that results from one facility will be more similar compared to results from other facilities. Due to this data structure, many statistical analyses used for comparing between categories (such as t-tests) are not appropriate because the assumption of independence between samples is not met, which would lead to inaccurate results. Therefore, linear mixed effects (LME) models were applied as a useful tool to account for the random effects of each individual facility and sampling 
event and reduce the possibility of obtaining false positives or false negatives (Harrison et al., 2018).

LME models were fit for each water quality parameter in $\mathrm{R}$ version 3.5.2 (R Core Team, 2018). The datasets for some of the measured parameters include multiple nondetect values (values below the method detection limit), which necessitated the use of a censored version of the mixed effect model. Therefore, the R package brms was used to fit Bayesian linear mixed effects models for censored data (Bürkner, 2016). Models were fit for each analyte concentration with treatment (representing treatment by the facility with inflow=false and outflow=true) and season (fall, winter or spring) as fixed effects. Facility ID and sample event (a term used to group inflow and outflow values together as individual events) were modeled as random effects. All models were fit using the log of the analyte concentration due to the multiplicative relationship expected and the lognormal distribution of most analyte values. When the resulting model indicated no effect of seasonality on the analyte measurement, then season was removed, and the model was run using only treatment as a fixed effect. Model results were used to determine percent removal from inflow to outflow (representing treatment effectiveness) and the $95 \%$ confidence interval for the percent removal. Negative percent reduction values indicate a percent increase.

Means, standard deviations, and medians for inflow and outflow were calculated for each analyte. For the purpose of calculating means and medians, non-detect observations were set at half of the method detection limit. 


\section{Results and Discussion}

A total of 52 samples were collected, representing a total of 18 storm events spanning approximately two years. All samples were collected between November and May, consistent with Portland's typical climate of wet winters and dry summers (although samples are lacking from the early portion of the rainy season). The number of observations per facility varies due to the inherent challenges in storm sampling and lack of flow or overflow at some facilities. Facility 2 was sampled 10 times; facilities 3, 8, and 14 were sampled 8 times; and facilities 13, 10 and 12 were sampled 7, 6, and 5 times, respectively (refer to Table 2).

Table 2: Number of samples total, per facility, and for each defined season.

\begin{tabular}{ccccc}
\hline Facility & $\begin{array}{c}\text { Total } \\
\text { Samples }\end{array}$ & $\begin{array}{c}\text { Fall } \\
\text { Samples }\end{array}$ & $\begin{array}{c}\text { Winter } \\
\text { Samples }\end{array}$ & $\begin{array}{c}\text { Spring } \\
\text { Samples }\end{array}$ \\
\hline F2 & 10 & 2 & 2 & 6 \\
F3 & 8 & 2 & 1 & 5 \\
F8 & 8 & 2 & 3 & 3 \\
F10 & 6 & 1 & 4 & 1 \\
F12 & 5 & 1 & 3 & 1 \\
F13 & 7 & 1 & 4 & 2 \\
F14 & 8 & 1 & 4 & 3 \\
\hline Totals & 52 & 10 & 21 & 21
\end{tabular}

Analyses for total $\mathrm{P}$, total and dissolved $\mathrm{Cu}$, and total and dissolved $\mathrm{Zn}$ concentrations are based on data collected by BES only and, therefore, have fewer observations.

The following sections describe results for each measured water quality parameter. Ideally, the observed values would be compared to water quality criteria 
established specifically for stormwater runoff in order to provide a basis for comparison. However, no such criteria exist in Oregon for urban stormwater runoff. Most established water quality criteria (either statewide or watershed-specific) apply to instream water quality instead of stormwater runoff. Stormwater-specific water quality benchmarks are provided by Oregon DEQ for industrial sites that are required to monitor stormwater runoff for the purpose of their 1200-Z permit (Oregon DEQ, 2017). However, not all analytes measured by this study have either established instream water quality criteria or DEQ benchmark values. When available, the results below are compared to available criteria to provide a general basis for comparison. However, these should not be interpreted as an applicable regulatory requirement since the standards do not technically apply to urban stormwater runoff.

\section{Total Suspended Solids}

Of the water quality parameters measured, total suspended solids showed the most significant change between influent and effluent. Mean inflow TSS was $67.0 \mathrm{mg} / \mathrm{L}$ $(S D=64.4)$ and mean outflow TSS was $5.3 \mathrm{mg} / \mathrm{L}(\mathrm{SD}=4.4)$. Based on the LME model, TSS outflow was 0.061 times inflow, indicating an approximately $93.9 \%$ decrease in TSS from inflow to outflow (95\% Cl: $90.1 \%$ to $96.2 \%$; Table 3 ). Input levels of TSS varied by facility but all facilities showed consistent effective reduction in TSS (Figure 4). These results are consistent with many similar studies (Bratieres et al., 2008; Davis et al., 2009; Hatt et al., 2009) and exceed the COP Stormwater Management Manual requirement that 
stormwater treatment facilities obtain 70 percent removal of TSS (Bureau of

Environmental Services, 2016).

The water quality standard for TSS for all freshwater streams and tributaries is established at $100 \mathrm{mg} / \mathrm{L}$ (Oregon DEQ, 2004). The lowest statewide benchmark for TSS in industrial stormwater runoff is $30 \mathrm{mg} / \mathrm{L}$ (Oregon DEQ, 2017). For inflow samples, approximately $65 \%$ exceeded the $30 \mathrm{mg} / \mathrm{L}$ benchmark and $23 \%$ exceeded the $100 \mathrm{mg} / \mathrm{L}$ standard. Treatment by the bioretention facility effectively reduced all outflow samples below the $30 \mathrm{mg} / \mathrm{L}$ benchmark.

Table 3: Summary table of inflow, outflow and percent reduction for TSS.

\begin{tabular}{|c|c|c|c|c|c|c|c|c|c|}
\hline \multirow[b]{2}{*}{ Parameter } & \multicolumn{3}{|c|}{ In } & \multicolumn{3}{|c|}{ Out } & \multicolumn{3}{|c|}{ Percent Reduction } \\
\hline & Mean & SD & Median & Mean & SD & Median & Percent Reduction & Lower Cl & Upper Cl \\
\hline TSS (mg/L) & 66.9 & 64.4 & 45 & 4.4 & 4.8 & 1.5 & $93.9 \%$ & $90.1 \%$ & $96.2 \%$ \\
\hline
\end{tabular}

Note:

Negative percent reduction indicates a percent increase
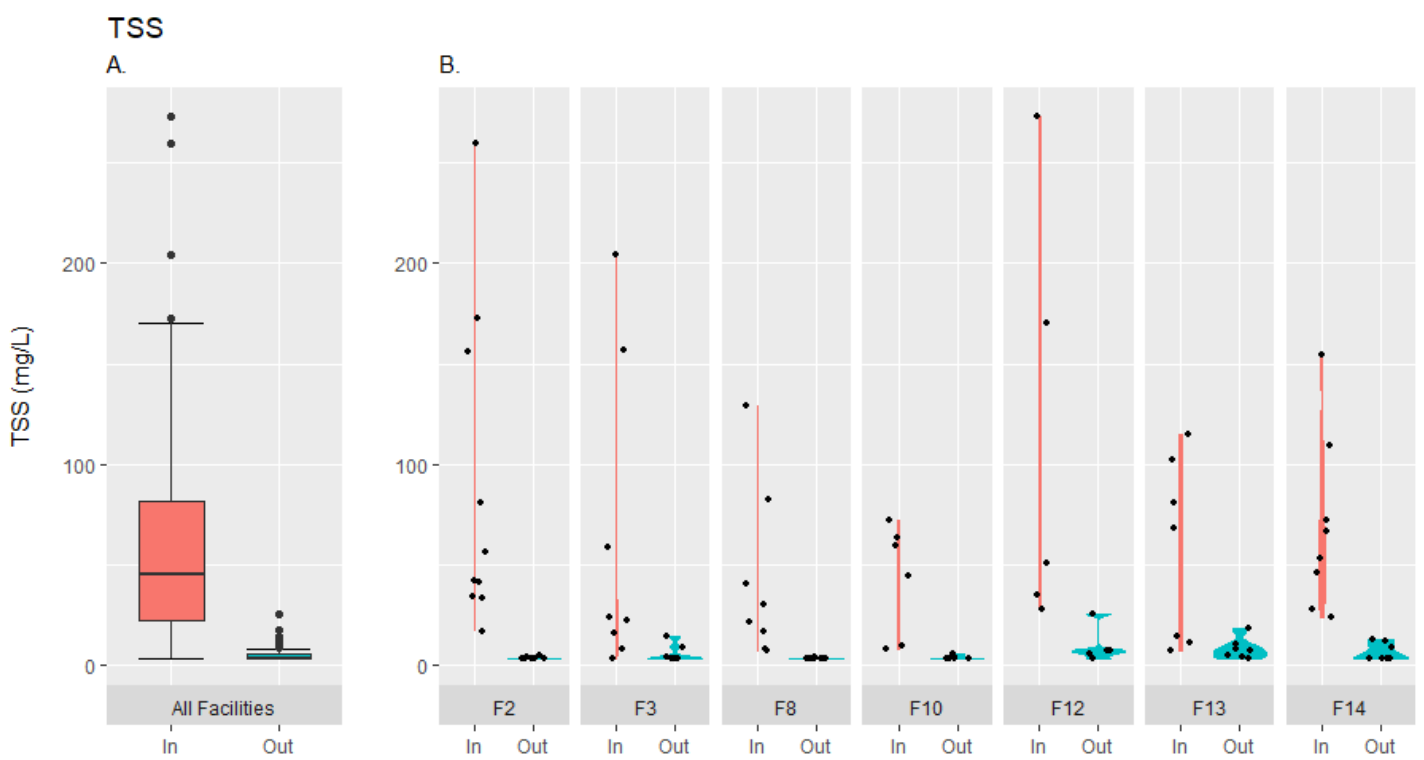

Figure 4: Range of TSS values for inflow and outflow for all facilities (A.) and each facility (B.). 


\section{$\underline{\text { Total and Dissolved Zinc }}$}

All results for $\mathrm{Zn}$ (both total and dissolved) were above the method detection limits. Mean inflow for total Zn was $104.3 \mu \mathrm{g} / \mathrm{L}(\mathrm{SD}=76.1)$ and mean outflow was 19.0 $\mu \mathrm{g} / \mathrm{L}(\mathrm{SD}=13.0)$. Mean inflow for dissolved $\mathrm{Zn}$ was $22.8 \mu \mathrm{g} / \mathrm{L}(\mathrm{SD}=14.9)$ and mean outflow was $14.5 \mu \mathrm{g} / \mathrm{L}(\mathrm{SD}=9.8$ ). For total $\mathrm{Zn}$, results from the LME model showed an estimated $80.4 \%$ (95\% Cl: $74.6 \%$ to $84.9 \%$ ) decrease by bioretention facilities (Table 4 ). All facilities consistently showed a decrease in total $\mathrm{Zn}$, although input levels did vary between facilities (Figure 5). Results for dissolved $\mathrm{Zn}$ also show an overall decrease from inflow to outflow, although the decrease is lower. The model estimate showed a $41.1 \%$ (95\% Cl: $25.9 \%$ to $52.8 \%$ ) decrease in dissolved $\mathrm{Zn}$ (Table 4). Although the model results consistently show a decrease through the facilities, facility 12 shows the opposite trend and appears to be exporting dissolved Zn (Figure 6). However, there are very few data points for facility 12; additional data collection and analysis would be necessary to determine if and why this facility is functioning differently than others for dissolved $\mathrm{Zn}$ removal.

Site-specific water quality criteria for $\mathrm{Zn}$ are calculated based on water chemistry to account for changes in bioavailability (Oregon DEQ, 2004). The criteria for $\mathrm{Zn}$ are calculated using water hardness, which was not measured for these stormwater samples. In lieu of calculating site-specific Zn criteria, we will compare to the total Zn statewide benchmark value for industrial stormwater runoff of $120 \mu \mathrm{g} / \mathrm{L}$ (Oregon DEQ, 
2017). For inflow samples, $32 \%$ exceeded this standard. The bioretention facilities effectively reduced all samples below the $120 \mu \mathrm{g} / \mathrm{L}$ standard.

Literature results generally indicate effective removal of total and dissolved $\mathrm{Zn}$ through bioretention treatment (Davis et al., 2009). Results from a newly installed bioretention facility in Redmond, WA, consistently showed effective total and dissolved Zn removal. During the second year of use, observed reductions for total and dissolved Zn were $89 \%$ and $43 \%$, respectively, which are very similar to percent reductions observed through this research (Herrera Environmental Consultants, Inc., 2014). Results from a field study of one newly installed bioretention facility in New Zealand showed much higher median inflow total and dissolved Zn values compared to this study (659 and $355 \mu \mathrm{g} / \mathrm{L}$, respectively). However, the facility still effectively reduced these values to 29 and $24 \mu \mathrm{g} / \mathrm{L}$, respectively.

Table 4: Summary table of inflow, outflow and percent reduction for total and dissolved Zn.

\begin{tabular}{|c|c|c|c|c|c|c|c|c|c|}
\hline \multirow[b]{2}{*}{ Parameter } & \multicolumn{3}{|c|}{ In } & \multicolumn{3}{|c|}{ Out } & \multicolumn{3}{|c|}{ Percent Reduction } \\
\hline & Mean & SD & Median & Mean & SD & Median & $\begin{array}{c}\text { Percent } \\
\text { Reduction }\end{array}$ & $\begin{array}{l}\text { Lower } \\
\mathrm{Cl}\end{array}$ & $\begin{array}{c}\text { Upper } \\
\text { Cl }\end{array}$ \\
\hline Total Zinc (ug/L) & 104.3 & 76.1 & 94.9 & 19.0 & 13.0 & 14.3 & $80.4 \%$ & $74.6 \%$ & $84.9 \%$ \\
\hline $\begin{array}{l}\text { Dissolved Zinc } \\
\text { (ug/L) }\end{array}$ & 22.8 & 14.9 & 18.1 & 14.5 & 9.8 & 12.3 & $41.1 \%$ & $25.9 \%$ & $52.8 \%$ \\
\hline
\end{tabular}



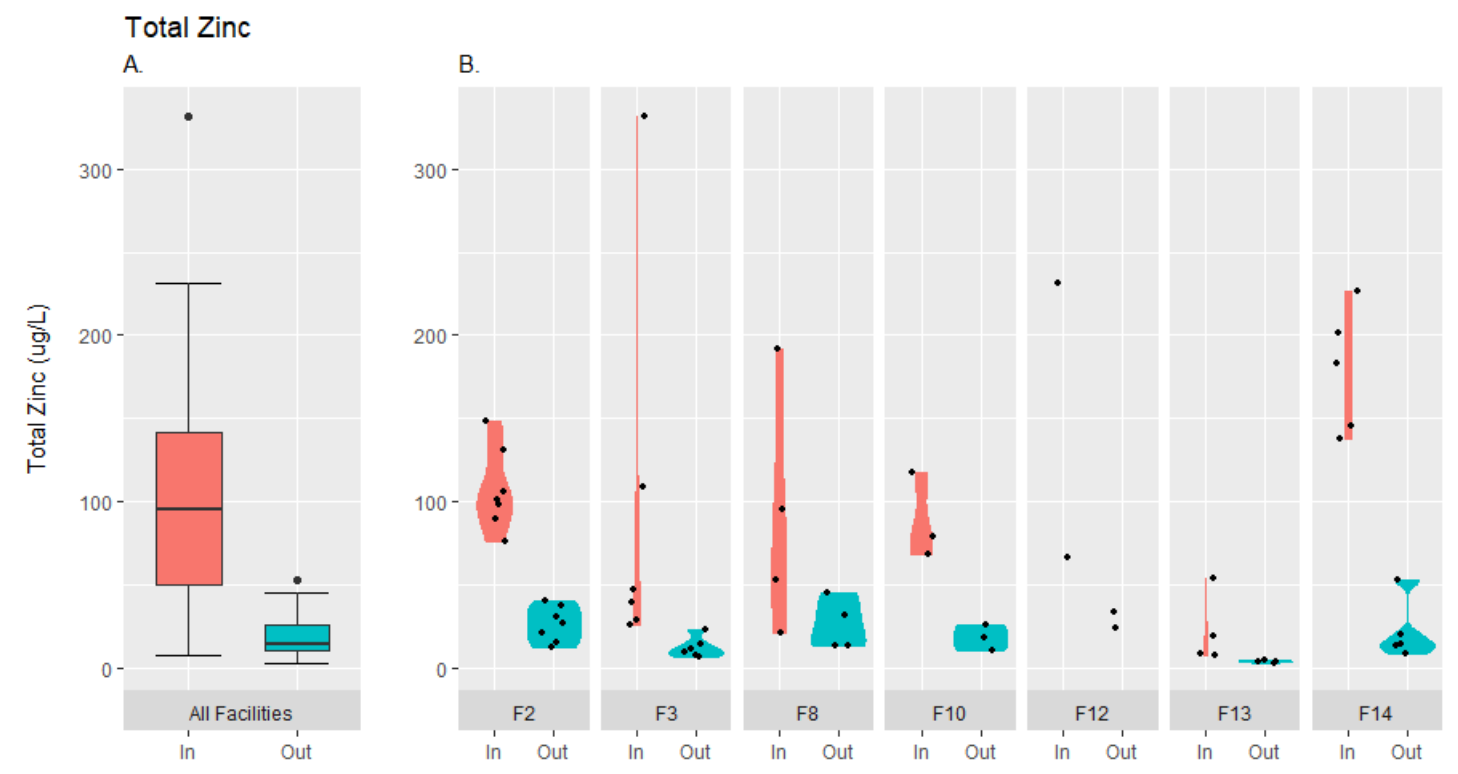

Figure 5: Range of total $\mathrm{Zn}$ values for inflow and outflow for all facilities (A.) and each facility (B.).
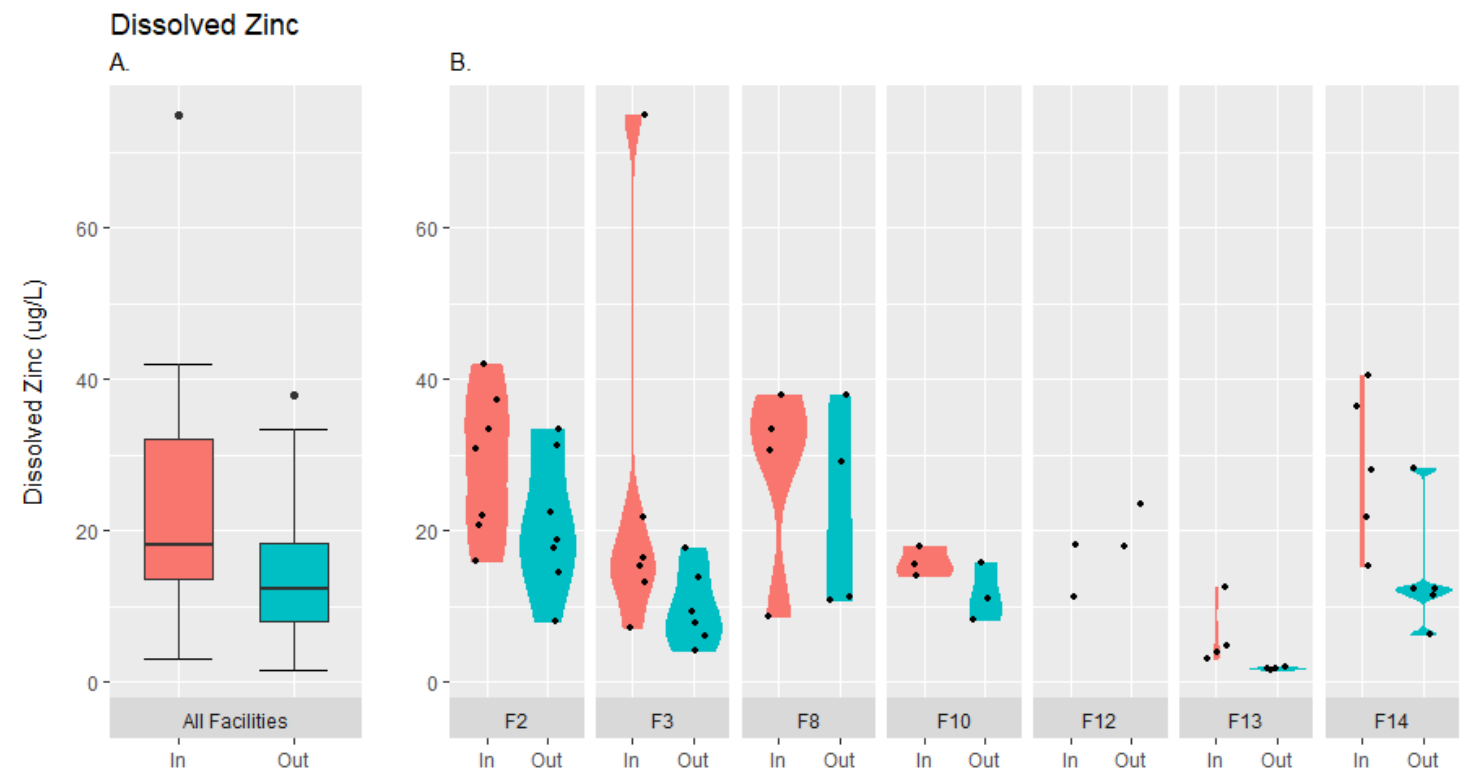

Figure 6: Range of dissolved $\mathrm{Zn}$ values for inflow and outflow for all facilities (A.) and each facility (B.).

\section{$\underline{\text { Total and Dissolved Copper }}$}

No results for $\mathrm{Cu}$ (both total and dissolved) were below the method detection limits. Mean inflow for total Cu was $20.2 \mu \mathrm{g} / \mathrm{L}(\mathrm{SD}=17.1$ ) and mean outflow was 6.3 
$\mu \mathrm{g} / \mathrm{L}(\mathrm{SD}=3.2)$. Mean inflow for dissolved Cu was $5.0 \mu \mathrm{g} / \mathrm{L}(\mathrm{SD}=4.7)$ and mean outflow was $5.0 \mu \mathrm{g} / \mathrm{L}(\mathrm{SD}=2.5)$. For total $\mathrm{Cu}$, model results estimated that the output is 0.405 times input, which is an estimated $59.3 \%(95 \% \mathrm{Cl}: 44.0 \%$ to $70.6 \%$ ) decrease (Table 5). Inflow levels of total Cu varied between facilities, with facility 12 and 14 having especially high inflow levels of total $\mathrm{Cu}$ (Figure 7). In contrast to observed reductions in total $\mathrm{Cu}$, model results for dissolved $\mathrm{Cu}$ showed an overall export with outflow values approximately 1.23 (95\% Cl: 0.93 to 1.62 ) times the inflow values (Table 5). This shows an estimated $23 \%$ increase in dissolved $\mathrm{Cu}$ from the bioretention facilities, although variability between facilities is high; some facilities appear to be exporting dissolved $\mathrm{Cu}$ (facilities 2, 10, 12 and 13) while others appear to reduce levels or have little to no effect (such as facilities 3, 8 and 14; Figure 8).

Cu water quality standards are determined using the Biotic Ligand Model (BLM), which takes into account variability in metal bioavailability by using other water chemistry parameters to calculate site-specific water quality criteria (Oregon DEQ, 2004). Given that this model is not applicable to stormwater runoff and that many of the input water quality parameters for the model were not collected for this project, we did not attempt to calculate individual $\mathrm{Cu}$ criteria values for each sample. Instead, we refer to the total $\mathrm{Cu}$ statewide benchmark value for industrial stormwater runoff of 20 $\mu \mathrm{g} / \mathrm{L}$ (Oregon DEQ, 2017). Of the inflow samples collected, 39\% exceeded this criterion. Treatment by the bioretention facilities effectively reduced all of the outflow samples below the $20 \mu \mathrm{g} / \mathrm{L}$ criterion. 
Although there appears to be some variability in the literature regarding $\mathrm{Cu}$ removal effectiveness of bioretention facilities, the results observed in this study are consistent with much of the available data. For example, a field study of one newly installed bioretention facility receiving runoff from a light industrial area showed a similar trend for $\mathrm{Cu}$ as observed in this study; the median for dissolved Cu effluent was higher than the influent median concentration, but total Cu showed an overall decrease in concentration for the same facility. Median concentrations of total and dissolved $\mathrm{Cu}$ in effluent were $15 \mu \mathrm{g} / \mathrm{L}$ and $23 \mu \mathrm{g} / \mathrm{L}$, respectively, which are both higher than median results observed in this study (Trowsdale and Simcock, 2011). A study by Li and Davis (2007) modeled heavy metal capture and accumulation in bioretention soils and compared the model to field data. Based on this analysis, they determined that washout of dissolved Cu may be observed in bioretention facilities. They attributed release of dissolved $\mathrm{Cu}$ to media desorption at the bottom of the facility (since $\mathrm{Cu}$ is primarily removed at the surface, percolating water will have especially low levels of $\mathrm{Cu}$ at the bottom of the facility), dissolved Cu's weak strength of association with the soil media, and its propensity to bind with organic matter (Li and Davis, 2008). A different study tested $\mathrm{Cu}$ leaching from compost (a commonly added component of bioretention media) and found that leaching of $\mathrm{Cu}$ from the compost fraction of the media can continue for many years and that $\mathrm{Cu}$ is primarily leached in the dissolved form (Mullane et al., 2015). In Redmond, WA, monitoring of a newly installed bioretention facility showed initial flushing of dissolved Cu during the first year of use. During the second 
year, effluent $\mathrm{Cu}$ levels were generally higher compared to influent, but the difference was not statistically significant. Effluent levels of dissolved Cu during the second year were between 4 and $17 \mu \mathrm{g} / \mathrm{L}$ and, similarly to the results of this study, showed significant variability (Herrera Environmental Consultants, Inc., 2014).

Based on a general assessment of facility characteristics such as age, street classification, adjacent uses, and sizing ratio, it is unclear what is driving the observed differences in dissolved Cu treatment between facilities. Observed variability may be due to differences in soil $\mathrm{Cu}$ content, the amount of imported $\mathrm{Cu}$ from stormwater runoff, availability of sorption sites, vegetation species, vegetation coverage, and other soil characteristics.

Results indicating effective removal of $\mathrm{Zn}$ but leaching of $\mathrm{Cu}$ from facilities are not consistent with research indicating that $\mathrm{Cu}$ will often outcompete $\mathrm{Zn}$ for sorption sites (Elliott et al., 1986; Morgan et al., 2011). However, studies have also shown that $\mathrm{Cu}$ interacts strongly with organic matter to form soluble complexes (Chahal et al., 2016; Mullane et al., 2015). Released organic matter from bioretention facilities (especially compost in the facilities) can therefore mobilize and leach $\mathrm{Cu}$, which may explain the observed trend for dissolved Cu. Although some leaching of dissolved Cu was observed, studies have shown reduced toxicity and bioavailability of copper when associated with dissolved organic matter; therefore, copper leached from bioretention facilities is expected to be less toxic to aquatic organisms in downstream receiving systems (Chahal et al., 2016; Linbo et al., 2009; McIntyre et al., 2008). 
Table 5: Summary table of inflow, outflow and percent reduction for total and dissolved Cu.

\begin{tabular}{|c|c|c|c|c|c|c|c|c|c|}
\hline \multirow[b]{2}{*}{ Parameter } & \multicolumn{3}{|c|}{ In } & \multicolumn{3}{|c|}{ Out } & \multicolumn{3}{|c|}{ Percent Reduction } \\
\hline & Mean & SD & Median & Mean & SD & Median & $\begin{array}{c}\text { Percent } \\
\text { Reduction }\end{array}$ & $\begin{array}{l}\text { Lower } \\
\mathrm{Cl}\end{array}$ & $\begin{array}{l}\text { Upper } \\
\text { Cl }\end{array}$ \\
\hline Total Copper (ug/L) & 20.2 & 17.1 & 16.5 & 6.3 & 3.2 & 5.5 & $59.3 \%$ & $44.0 \%$ & $70.6 \%$ \\
\hline $\begin{array}{l}\text { Dissolved Copper } \\
\text { (ug/L) }\end{array}$ & 5.0 & 4.7 & 3.6 & 5.0 & 2.5 & 4.6 & $-23.4 \%$ & $-6.8 \%$ & $-61.6 \%$ \\
\hline
\end{tabular}

Note:

Negative percent reduction indicates a percent increase
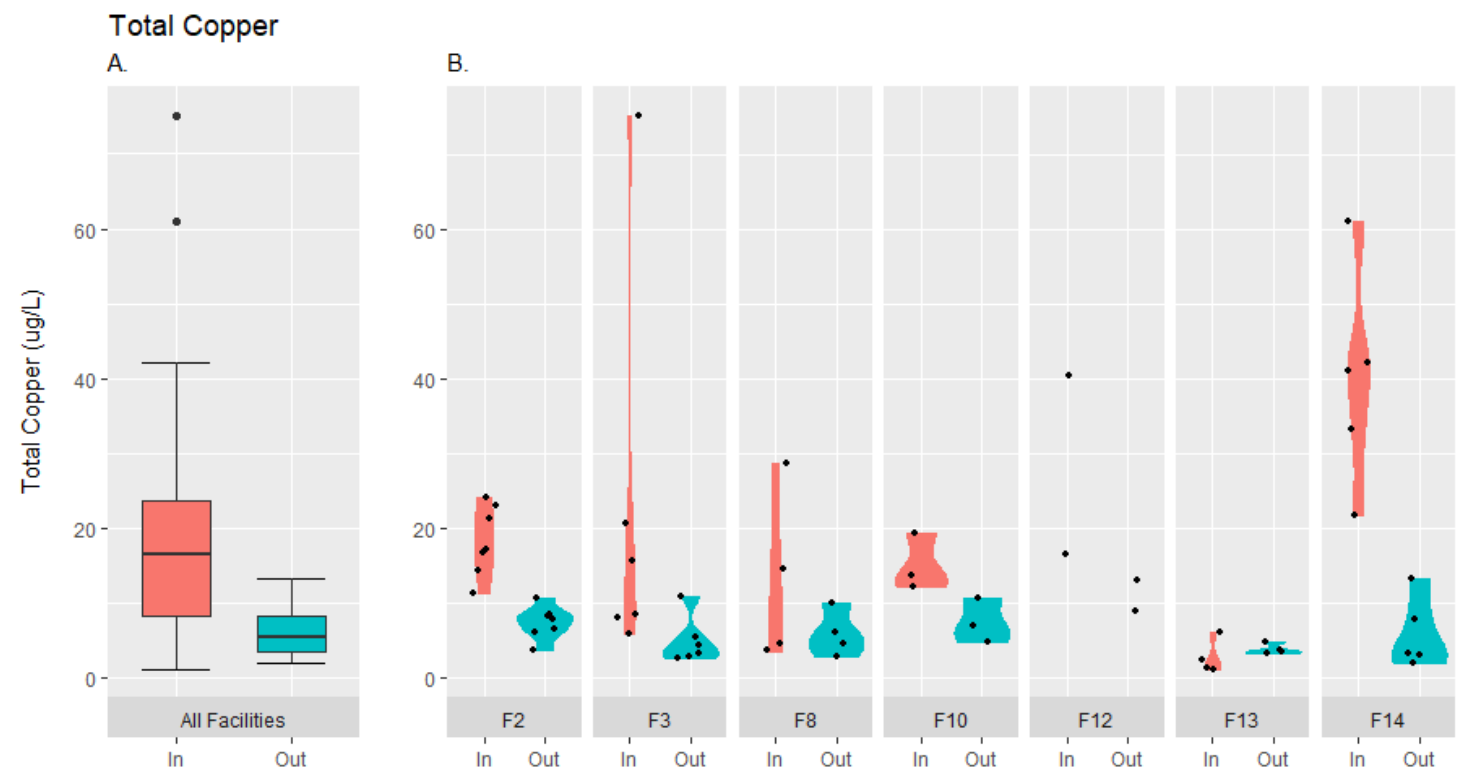

Figure 7: Range of total Cu values for inflow and outflow for all facilities (A.) and each facility (B.). 

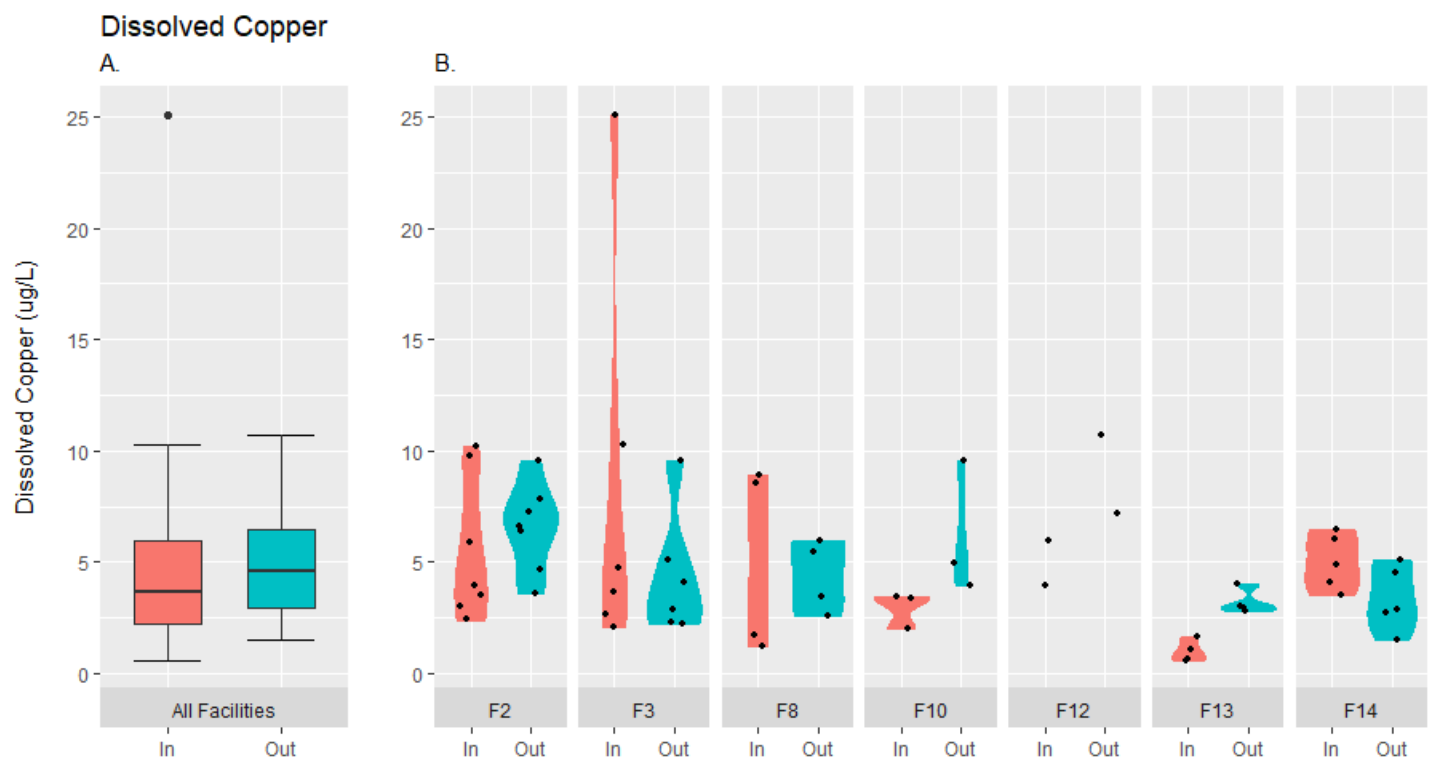

Figure 8: Range of dissolved Cu values for inflow and outflow for all facilities (A.) and each facility (B.).

\section{Phosphorus}

For orthophosphate, 16 of 52 inflow samples were below the method detection limits (0.02 for BES samples and 0.01 for PSU samples) and 4 of 52 outflow samples were below the detection limit. Mean orthophosphate inflow values were $0.088 \mathrm{mg}-\mathrm{P} / \mathrm{L}$ $(S D=0.166)$ and mean outflow levels were $0.124 \mathrm{mg}-\mathrm{P} / \mathrm{L}(\mathrm{SD}=0.130)$. Outflow samples for orthophosphate were estimated to be 2.41 times the inflow ( $95 \% \mathrm{Cl}: 1.77$ to 3.29$)$, indicating an export of orthophosphate from the bioretention facilities of approximately 141\% (Table 6). Between-facility variability of orthophosphate was high (Figure 10). For example, facility 14 overall had very low inflow and outflow orthophosphate levels, and facility 12 and 13 had the highest inflow levels. Facility 14 treats runoff from an elevated light-rail track (as shown in Figure 9), which may limit its exposure to many of the 
common P sources in stormwater including eroding soil, fertilizers, plant detritus, detergents, and pet waste. This could be one potential explanation for the low observed levels in this facility. Facilities 12 and 13 both appear to have the most significant adjacent tree canopy cover, which could contribute to their elevated orthophosphate levels.

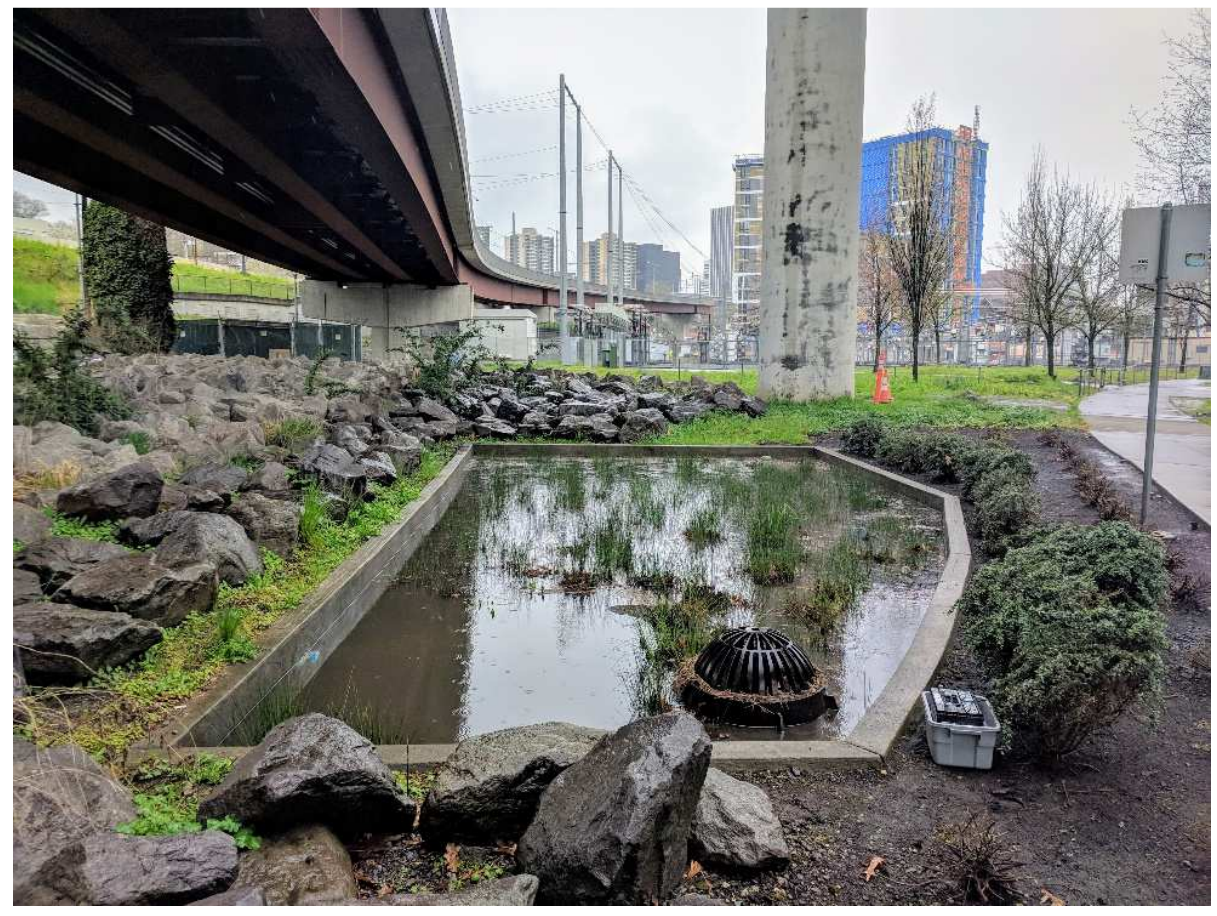

Figure 9: Photo of facility 14 showing the bioretention facility and the elevated light rail track that drains to it.

The observed increase in orthophosphate is not consistent with the overall observed decrease in TSS; therefore, decreased levels of TSS should not be used as a proxy for orthophosphate removal effectiveness in bioretention facilities. 

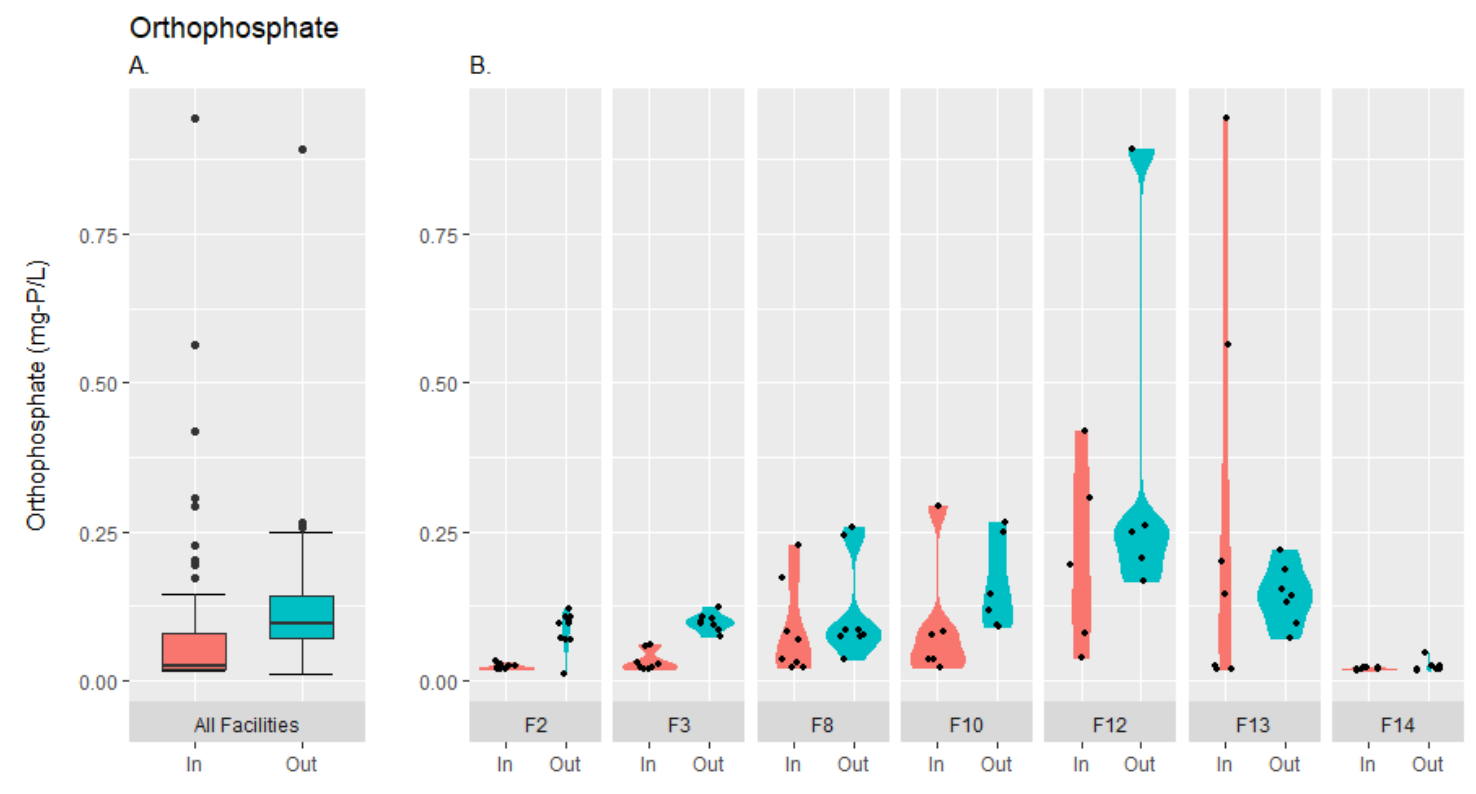

Figure 10: Range of orthophosphate values for inflow and outflow for all facilities (A.) and each facility (B.).

Results for total P showed an overall decrease in the outflow. The mean inflow for total $P$ was $0.186 \mathrm{mg}-\mathrm{P} / \mathrm{L}(\mathrm{SD}=0.172)$ and the mean outflow was $0.109 \mathrm{mg}-\mathrm{P} / \mathrm{L}(\mathrm{SD}=$ 0.062). The model estimated a 33.0\% decrease of total $P$ from inflow to outflow (Table 6), although variability of results was high ( $95 \% \mathrm{Cl}: 10.4 \%$ to $49.8 \%)$. Facilities 12 and 13 showed especially high total P inputs, and facility 14 had very low inputs and outflow levels (Figure 11), consistent with results described above for orthophosphate. No results for total $\mathrm{P}$ were below the method detection limits. 

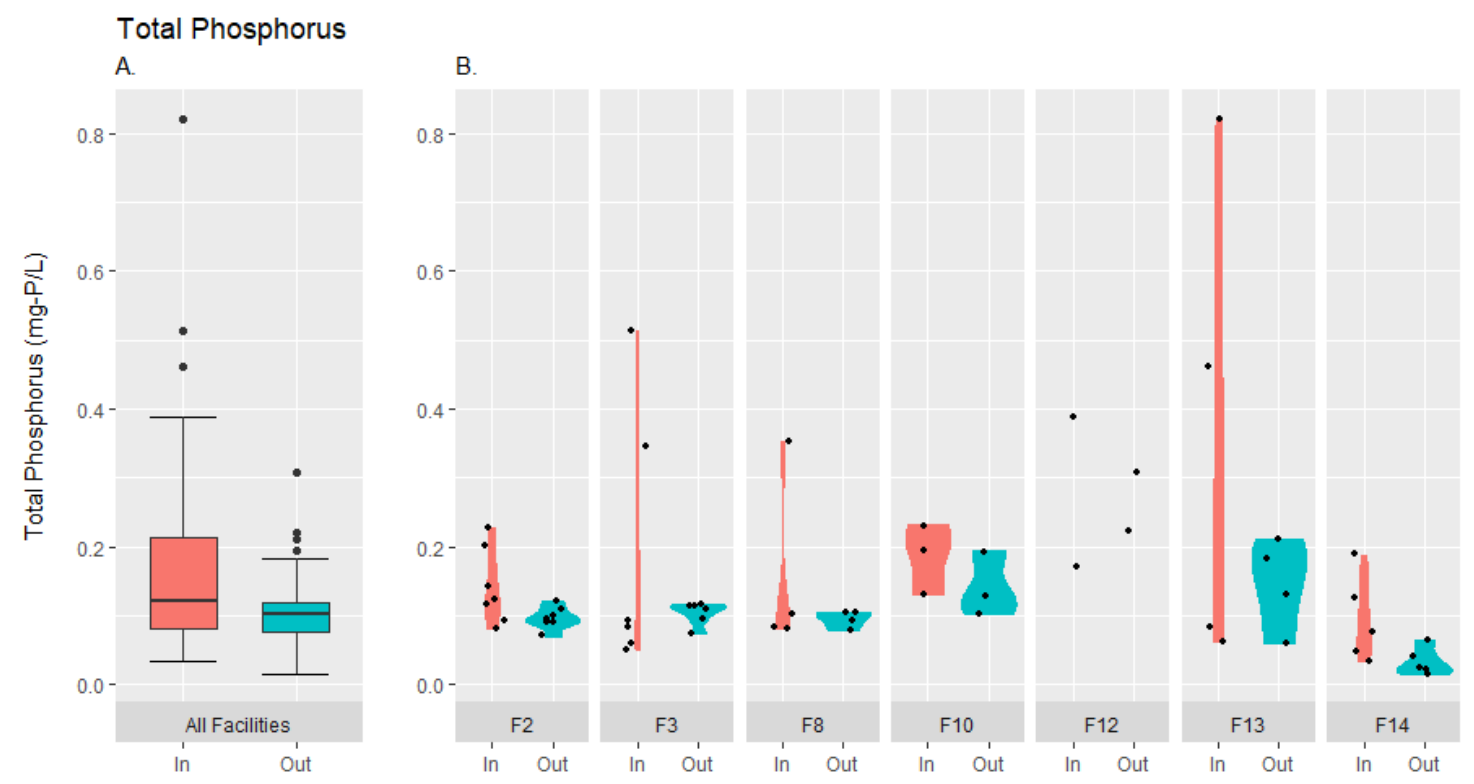

Figure 11: Range of total phosphorus values for inflow and outflow for all facilities (A.) and each facility (B.).

The Columbia Slough TMDL defines a maximum instream criterion for total P of $0.1549 \mathrm{mg}-\mathrm{P} / \mathrm{L}$ (Oregon DEQ, 1998). For total P, 39\% of inflow samples exceeded this value. Treatment by the bioretention facility reduced this to $16 \%$ exceeding the criterion for outflow samples. There is no specific criterion established for orthophosphate. However, comparing orthophosphate values to the total P criterion shows that $17 \%$ of inflow samples exceed this criterion and this was increased to $21 \%$ following treatment by the bioretention facility.

Total $\mathrm{P}$ is generally retained in bioretention facilities due to the efficient removal of suspended sediment (LeFevre et al., 2015). However, bioretention facilities can leach P from organic matter in the facility and from minerals in the soil media, depending on the P content of the soil (LeFevre et al., 2015). A recent PSU study tested P content of 16 bioretention facilities in Portland and determined that soil total P levels were generally 
high and variable between sites, which may partially explain the export of orthophosphate observed in this study (Shetterly, 2018). However, we do not know if the high levels of $\mathrm{P}$ have accumulated in the facility due to stormwater runoff or if the soil itself had high levels of $\mathrm{P}$ at the time of installation.

Results from similar studies show variable results for total P and orthophosphate treatment through bioretention. Results from a newly installed bioretention facility in Redmond, Washington had mean total P and orthophosphate effluent levels of 4.14 and $2.89 \mathrm{mg}-\mathrm{P} / \mathrm{L}$, respectively during the first year of operation. During the second year, these levels were 1.40 for total $\mathrm{P}$ and $1.187 \mathrm{mg}-\mathrm{P} / \mathrm{L}$ for orthophosphate. Both years showed a large increase from inflow to outflow (Herrera Environmental Consultants, Inc., 2014). In simulated bioretention columns, Chahal et al. (2016) observed total P outflow levels of 10-16 mg-P/L. Results from two bioretention systems in Australia showed variable results for total $\mathrm{P}$ and filterable reactive $\mathrm{P}$ with one facility leaching $\mathrm{P}$ while the other effectively reduced levels of P. For the facility that leached total and dissolved $P$, the outflow values were 0.16 to $0.22 \mathrm{mg}-\mathrm{P} / \mathrm{L}$ for total $\mathrm{P}$ and $0.10-0.11 \mathrm{mg}$ P/L for filterable reactive $P$ (Hatt et al., 2009).

Removal of orthophosphate in bioretention facilities involves two different processes: fast sorption to surface sites (can be reversible), and slower precipitation reactions between $\mathrm{P}$ and metal oxides (generally irreversible) (LeFevre et al., 2015). Multiple studies have looked to amendments (such as water treatment residuals, calcareous sand, limestone, fly ash and steel wool) to improve bioretention removal of 
dissolved P through sorption and precipitation (Erickson et al., 2007; Liu and Davis, 2014, 2014; Lucas and Greenway, 2011; O’Neill and Davis, 2012; Poor et al., 2018; Zhang et al., 2008). Current research shows preliminary success in improving dissolved $\mathrm{P}$ removal with many of the amendments (Liu and Davis, 2014). Based on the observed leaching of orthophosphates in the monitored facilities, it may be necessary to further assess and potentially implement use of a soil media amendment in order to improve the effectiveness of bioretention facilities for orthophosphate removal.

Table 6: Summary table of inflow, outflow and percent reduction for orthophosphate and total $P$.

\begin{tabular}{|c|c|c|c|c|c|c|c|c|c|}
\hline \multirow[b]{2}{*}{ Parameter } & \multicolumn{3}{|c|}{ In } & \multicolumn{3}{|c|}{ Out } & \multicolumn{3}{|c|}{ Percent Reduction } \\
\hline & Mean & SD & Median & Mean & SD & Median & $\begin{array}{l}\text { Percent } \\
\text { Reduction }\end{array}$ & $\begin{array}{l}\text { Lower } \\
\mathrm{Cl}\end{array}$ & $\begin{array}{c}\text { Upper } \\
\mathrm{CI}\end{array}$ \\
\hline Orthosphate (mg-P/L) & 0.088 & 0.166 & 0.026 & 0.124 & 0.130 & 0.096 & $-141 \%$ & $-76.8 \%$ & $-235 \%$ \\
\hline $\begin{array}{l}\text { Total Phosphorus (mg- } \\
\text { P/L) }\end{array}$ & 0.186 & 0.172 & 0.122 & 0.109 & 0.062 & 0.103 & $33.0 \%$ & $10.4 \%$ & $49.8 \%$ \\
\hline
\end{tabular}

Nitrogen

For ammonia, 12 of 52 inflow samples were below the method detection limits ( 0.02 for PSU samples and 0.05 for BES samples) and 33 of 50 outflow samples were below the detection limit. Mean ammonia inflow values were $0.220 \mathrm{mg}-\mathrm{N} / \mathrm{L}(\mathrm{SD}=0.219)$ and mean outflow values were $0.071 \mathrm{mg}-\mathrm{N} / \mathrm{L}(\mathrm{SD}=0.116)$. Based on the model results, treatment by the bioretention facilities decreased ammonia levels by $85.0 \%$ ( $95 \% \mathrm{Cl}$ :

71.9\% to 92.3\%; Table 7). Variability between bioretention facilities for ammonia removal was high: facilities 2 and 12 have especially high levels of ammonia in inflow and facility 10 had high variability in ammonia effluent levels (see Figure 12). High 
variability in ammonia removal is noted by other bioretention studies and may be attributable to differences in media cation exchange capacity or differences in microbial $\mathrm{N}$ processing (ammonification and nitrification rates) (Davis et al., 2009).

The Tualatin Basin Total Maximum Daily Load (TMDL) includes maximum loading capacity design concentrations for ammonia (Oregon DEQ, 2012). These design concentrations vary based on location and time of year. The most conservative concentration according to this TMDL is for the period between September $1^{\text {st }}$ and November $15^{\text {th }}$, which is defined as $0.195 \mathrm{mg}-\mathrm{N} / \mathrm{L}$ of ammonia. Approximately $40 \%$ of runoff samples collected prior to treatment by the bioretention facility exceeded the $0.195 \mathrm{mg}-\mathrm{N} / \mathrm{L}$ criteria. After treatment, this was reduced to $14 \%$ of samples exceeding the criteria. If we instead compare sampled values to a moderate design concentration instead of the most conservative (such as $0.68 \mathrm{mg}-\mathrm{N} / \mathrm{L}$ ), then the samples exceeding the criteria for inflow and outflow would be reduced to $3 \%$ and $0 \%$, respectively. No samples exceed the least conservative design concentration for the Tualatin Basin of $1.31 \mathrm{mg}-\mathrm{N} / \mathrm{L}$. Based on these results, there is some variability in ammonia removal between facilities, but overall bioretention facilities are effectively decreasing ammonia concentrations in stormwater runoff.

For nitrate, 31 of the 52 inflow samples were below the method detection limits (0.1 for BES samples and 0.02 for PSU samples) while only 2 of 52 outflow values were below the method detection limit. Mean inflow nitrate levels were $0.070 \mathrm{mg}-\mathrm{N} / \mathrm{L}$ (SD = $0.057)$ and mean outflow nitrate was $1.456 \mathrm{mg}-\mathrm{N} / \mathrm{L}(\mathrm{SD}=1.743)$. Based on the fitted 
model for the measured facilities, nitrate levels in the outflows were estimated to be 21.7 times higher than the inflow ( $95 \% \mathrm{Cl}: 14$ to 33 times higher). This is approximately equal to an estimated increase of $2070 \%$ (Table 7). All facilities consistently showed nitrate export; however, the variability in export amounts between facilities was high, with facilities 10 and 12 showing especially high nitrate export (Figure 13). It is unclear what may be causing facilities 10 and 12 to have higher levels of nitrate - they are the two oldest facilities, were installed under the same project (potentially using the same materials) and are located on the same busy street. However, many of the other facilities are located on equally busy streets and a few are only months younger. Therefore, additional analysis would be necessary to determine why these differences were observed.

The Oregon Department of Environmental Quality has not defined a water quality criterion for nitrate and no Portland area TMDLs include nitrate. Therefore, it is difficult to assess the extent to which the export of nitrate from bioretention facilities is a concern to local receiving water bodies. The Oregon DEQ industrial stormwater permit does include a sector-specific benchmark for nitrate of $0.68 \mathrm{mg}-\mathrm{N} / \mathrm{L}$ for industrial sites that fall under specific categories (such as production of agricultural chemicals, for example) (Oregon DEQ, 2017). The only other established standard for nitrate is $10 \mathrm{mg}$ N/L as established under the Safe Drinking Water Act (US EPA, 2009). No inflow or outflow samples exceeded the $10 \mathrm{mg}-\mathrm{N} / \mathrm{L}$ standard. None of the inflow samples exceeded $0.68 \mathrm{mg}-\mathrm{N} / \mathrm{L}$ of nitrate. However, approximately $56 \%$ of the outflow samples 
exceeded the $0.68 \mathrm{mg}-\mathrm{N} / \mathrm{L}$ sector-specific industrial stormwater benchmark. If this benchmark is indeed indicative of an accurate level of concern for nitrate in stormwater discharge, then the bioretention facilities caused over half of samples to exceed this value.

It is important to note that leaching of nitrate from the facilities is not consistent with the observed removal trend for TSS; therefore, decreased levels of TSS should not be used as a proxy for nitrate removal effectiveness in bioretention facilities.

Leaching of nitrate from bioretention facilities has been observed in multiple other studies (Brown et al., 2013; Chahal et al., 2016; Davis et al., 2006; Hatt et al., 2009; Herrera Environmental Consultants, Inc., 2014) and is generally attributed to $\mathrm{N}$ cycling within the facility. Organic $\mathrm{N}$ and ammonia taken up by bioretention facilities undergo nitrification between storm events, producing nitrate/nitrite that is flushed from the facility during subsequent storm events (Davis et al., 2006; Kim et al., 2003; Yang and Lusk, 2018). Nitrification is an aerobic process, which can occur in the bioretention soil media between storm events when stormwater has drained from the facility (Brown et al., 2013).

Results from other bioretention studies show significant variability in nitrate effluent levels. A study by Chahal et al (2016) observed nitrate plus nitrite levels of 4-34 $\mathrm{mg}-\mathrm{N} / \mathrm{L}$ in effluent from lab bioretention columns amended with compost over the course of seven simulated storm events. For two field sites using synthetic stormwater, Davis et al. (2006) observed effluent nitrate levels in the range of 0.2 to $0.4 \mathrm{mg}-\mathrm{N} / \mathrm{L}$ for 
one facility and 1 to $1.2 \mathrm{mg}-\mathrm{N} / \mathrm{L}$ for another facility; however, these facilities generally showed nitrate removal of 15 to $16 \%$ (not export, as observed in this study). Results from a combination of simulated and real storm events at three facilities in Australia had nitrate effluent levels of approximately 0.14 to $1.6 \mathrm{mg}-\mathrm{N} / \mathrm{L}$ and percent removal of 13 to $-17 \%$ (indicating export) (Hatt et al., 2009). Results from a newly installed bioretention facility in Redmond, Washington exhibited mean nitrate plus nitrite effluent levels of $53.78 \mathrm{mg}-\mathrm{N} / \mathrm{L}$ (percent reduction of $-31,971 \%$ ) during the initial flushing period during the first year of operation. Their results indicated that nitrate flushing stabilized during the second year of operation with mean effluent levels of 0.55 mg-N/L and mean removal of -198\% (Herrera Environmental Consultants, Inc., 2014). In response to observed nitrate release from bioretention facilities, research has focused on design modifications to improve denitrification potential. The primary recommendation involves adding a permanently inundated anoxic zone at the bottom of the facility to facilitate denitrification, which requires anaerobic conditions (Brown and Hunt, 2011; Dietz and Clausen, 2006; Hunt et al., 2006; Kim et al., 2003). Improvement of denitrification in bioretention facilities also necessitates providing a carbon source or other electron donor for denitrifying bacteria within the anoxic zone (Kim et al., 2003). Studies have evaluated potential amendments to provide this benefit including woodchips, newspaper, leaf mulch, alfalfa, sawdust, wheat straw, and elemental sulfur (Kim et al., 2003; Peterson et al., 2015). There is also some (although limited) research documenting the importance of vegetation species and root mass size 
for improving $\mathrm{N}$ removal in bioretention facilities (Bratieres et al., 2008; Passeport et al., 2009). Many of the above studies were lab-based or provided inconclusive results; therefore, additional research and field-scale studies are necessary to more accurately assess potential design modifications for nitrate removal.

It should be noted that samples analyzed by BES measured nitrate only, while samples analyzed at PSU measured nitrate plus nitrite. Although this introduces a potential error or inconsistency in the mean, the percent increase estimate is expected to be representative because of the paired comparison between inflow and outflow, which were always analyzed using the same method. In addition, due to fast oxidation of nitrite to nitrate, nitrite concentrations are generally very low compared to nitrate in surface waters, often below $0.1 \mathrm{mg} / \mathrm{L}$ (Minero et al., 2007; Sawyer et al., 2002).

Therefore, the difference in analysis methods is expected to have only a minor impact on calculated means.

Table 7: Summary table of inflow, outflow and percent reduction for ammonia and nitrate.

\begin{tabular}{|c|c|c|c|c|c|c|c|c|c|}
\hline \multirow[b]{2}{*}{ Parameter } & \multicolumn{3}{|c|}{ In } & \multicolumn{3}{|c|}{ Out } & \multicolumn{3}{|c|}{ Percent Reduction } \\
\hline & Mean & SD & Median & Mean & SD & Median & $\begin{array}{l}\text { Percent } \\
\text { Reduction }\end{array}$ & $\begin{array}{l}\text { Lower } \\
\mathrm{Cl}\end{array}$ & $\begin{array}{c}\text { Upper } \\
\text { Cl }\end{array}$ \\
\hline $\begin{array}{l}\text { Ammonium (mg- } \\
\mathrm{N} / \mathrm{L})\end{array}$ & 0.22 & 0.219 & 0.138 & 0.071 & 0.116 & 0.025 & $85.0 \%$ & $71.9 \%$ & $92.3 \%$ \\
\hline Nitrate (mg-N/L) & 0.07 & 0.057 & 0.050 & 1.456 & 1.743 & 0.758 & $-2076 \%$ & $-1373 \%$ & $-3245 \%$ \\
\hline
\end{tabular}



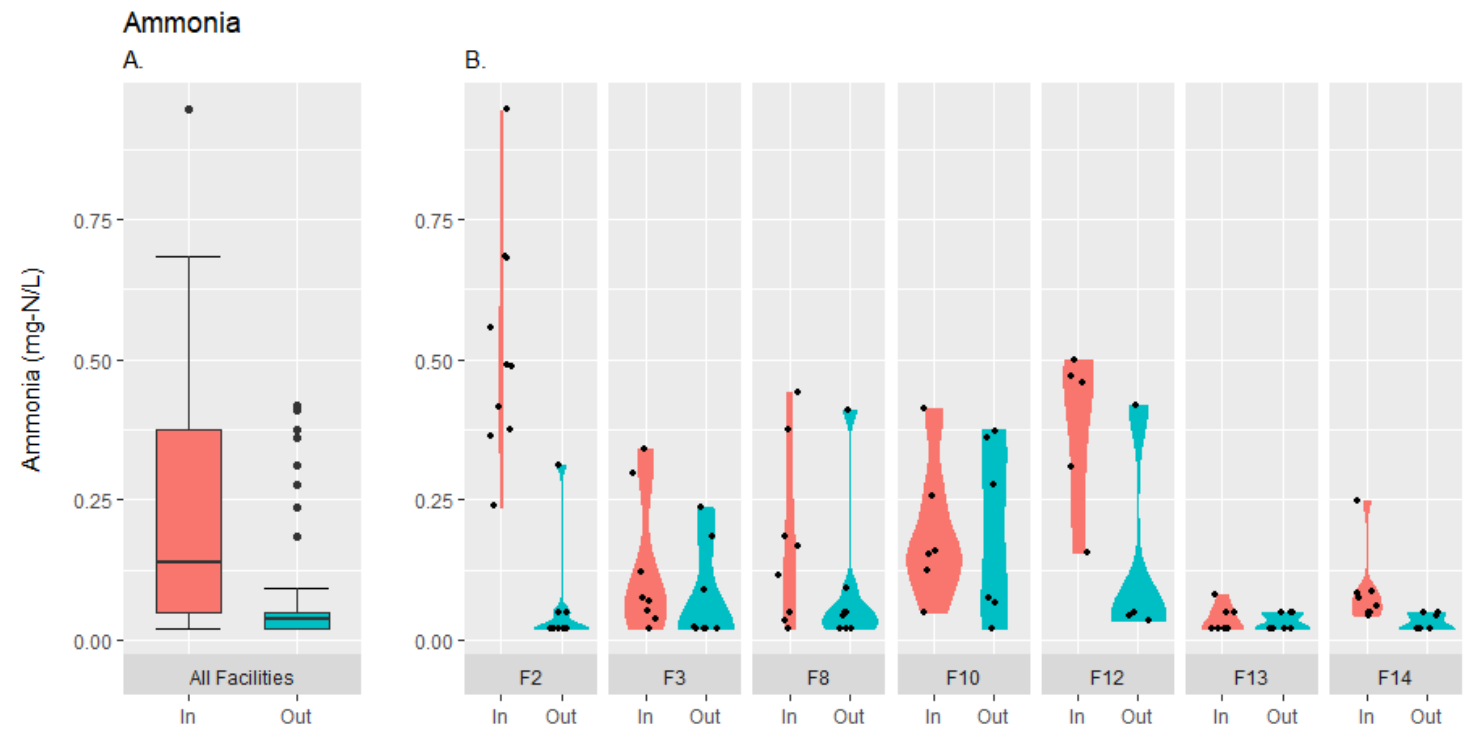

Figure 12: Range of ammonia values for inflow and outflow for all facilities (A.) and each facility (B.).

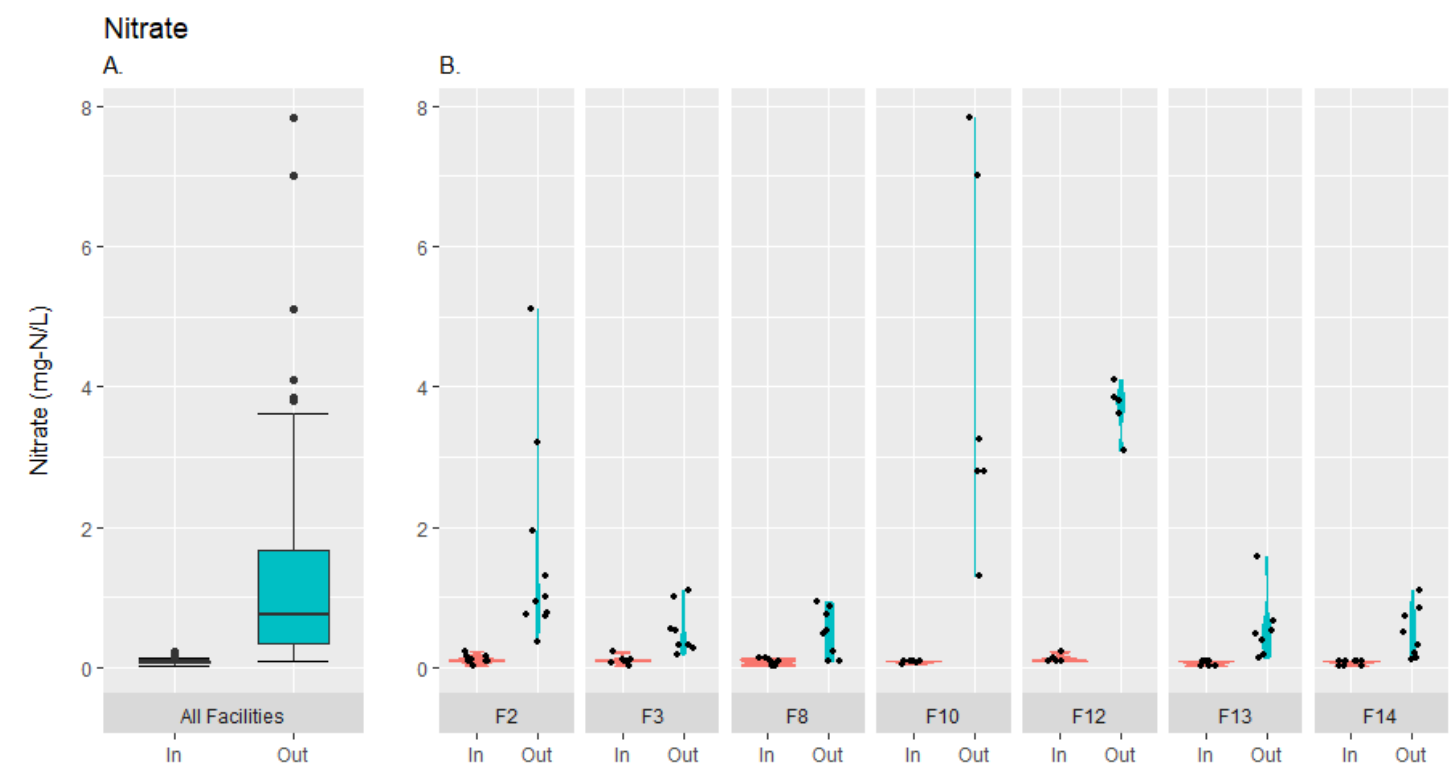

Figure 13: Range of nitrate values for inflow and outflow for all facilities (A.) and each facility (B.).

\section{General Water Quality Parameters}

Results for $\mathrm{pH}$ indicated a slight reduction between inflow and outflow. Mean

inflow pH was $6.9(\mathrm{SD}=0.5)$ and mean outflow was $6.5(\mathrm{SD}=0.4)$. Model results showed an estimated $5.8 \%$ decrease in $\mathrm{pH}$ from inflow to outflow $(95 \% \mathrm{Cl}: 3.9 \%$ to $6.8 \%$; Table 
8). Established instream water quality standards for $\mathrm{pH}$ in the Willamette River watershed is 6.5-8.5 (Oregon DEQ, 2004). The most conservative statewide benchmark for industrial stormwater $\mathrm{pH}$ is 5.5-8.5 (Oregon DEQ, 2017). No samples measured were above a pH of 8.5 (for inflow or outflow). Approximately $19 \%$ of inflow samples were below a pH of 6.5 while $60 \%$ of outflow samples were below a pH of 6.5 , indicating that bioretention facilities may be decreasing stormwater runoff below instream standards. When instead comparing to the industrial stormwater benchmark only one inflow sample was below a pH of 5.5 and no outflow samples were below 5.5 (Figure 14).

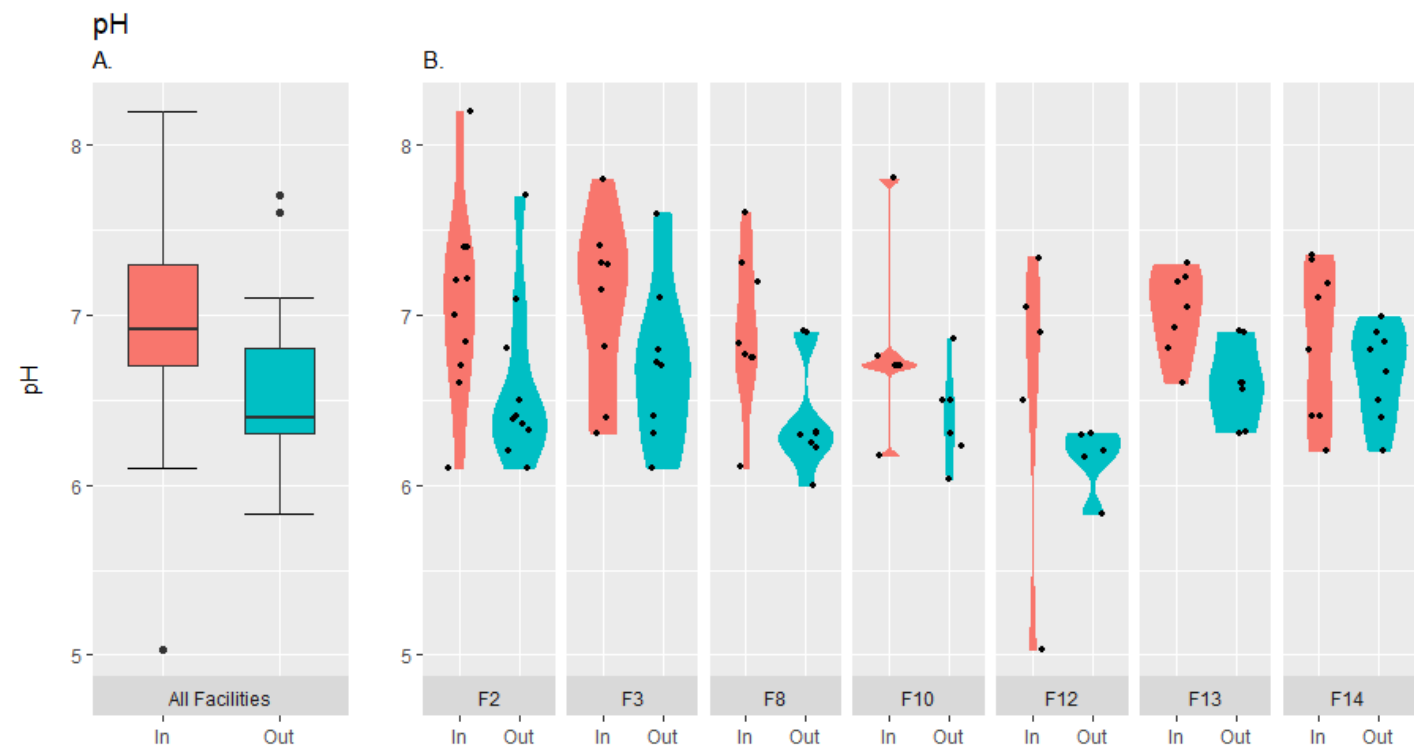

Figure 14: Range of $\mathrm{pH}$ values for inflow and outflow for all facilities (A.) and each facility (B.).

For conductivity, mean inflow was $34.3 \mu \mathrm{S} / \mathrm{cm}(\mathrm{SD}=24.1)$ and mean outflow was $49.3 \mu \mathrm{S} / \mathrm{cm}(\mathrm{SD}=28.9)$. Results from the LME model indicated an overall increase in conductivity from inflow to outflow with the outflow estimated to be 1.52 times the inflow (95\% $\mathrm{Cl} 1.3$ to 1.8 ). This is equivalent to an estimated $52 \%$ increase from inflow to 
outflow (Table 8 and Figure 15). Although Portland does occasionally apply deicing agents or salt to roads, it is unlikely that this increase is due to use of those substances because the catchment areas for this study are not identified by the City as salting or deicing roads. Conductivity is a measure of dissolved ions in water; therefore, the increase in nitrate and orthophosphate observed in this study could provide at least a partial explanation for the increased conductivity. Other ions not measured through this analysis may also contribute to the observed increase. Despite the overall increase, the observed levels of conductivity are not alarmingly high in comparison to average annual conductivity of Willamette River in Portland, which is generally between $70-80 \mu \mathrm{S} / \mathrm{cm}$ based on USGS data (USGS, n.d.).
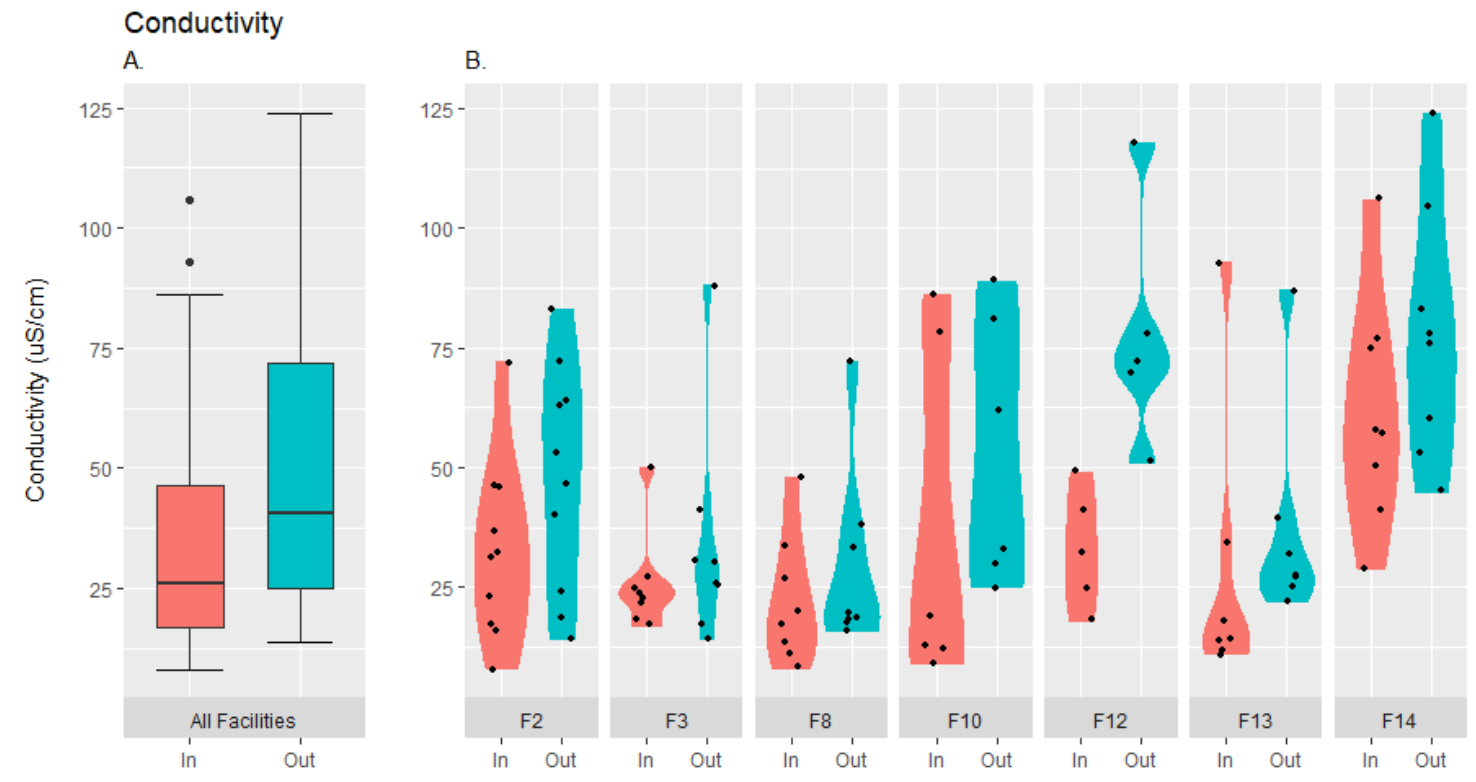

Figure 15: Range of conductivity values for inflow and outflow for all facilities (A.) and each facility (B.).

Dissolved oxygen results showed only a very minor decrease from inflow to outflow of approximately 3.0\% (95\% Cl: zero to $5.8 \%$ ). Mean inflow DO was $10.8 \mathrm{mg} / \mathrm{L}$ 
$(\mathrm{SD}=1.3)$ and mean outflow was $10.4 \mathrm{mg} / \mathrm{L}(\mathrm{SD}=1.1$; Table 8 and Figure 16). Dissolved oxygen water quality standards vary based on beneficial uses related to spawning habitat and cold water habitats (Oregon DEQ, 2004). The second most conservative standard (disregarding the most conservative, which is defined for active spawning areas) states that dissolved oxygen must not be less than $8.0 \mathrm{mg} / \mathrm{L}$ for water bodies that provide cold water habitat. The Columbia Slough TMDL also includes a standard for dissolved oxygen; however, it is less conservative than the standard designated for cold water habitat. Only one inflow sample and one outflow sample fell below the $8.0 \mathrm{mg} / \mathrm{L}$ dissolved oxygen standard.

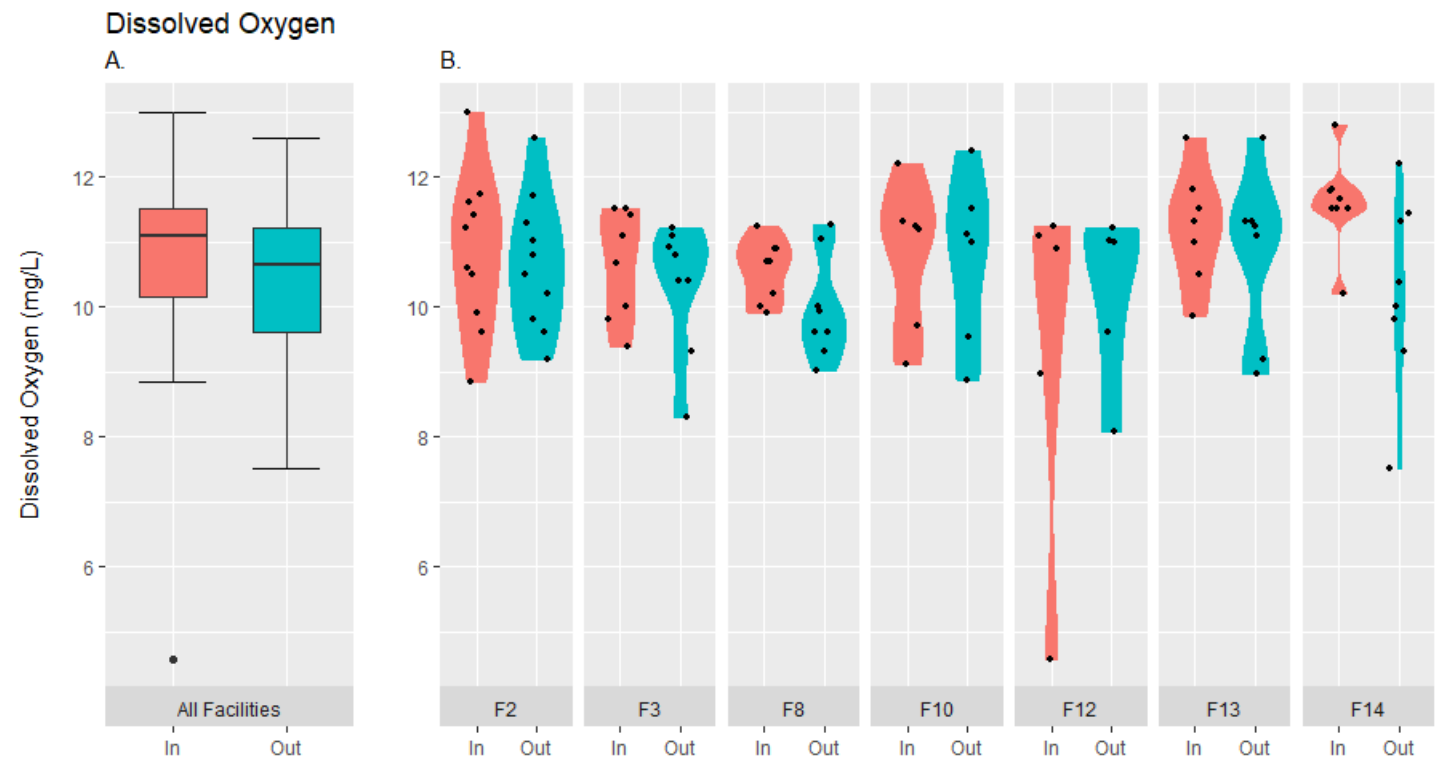

Figure 16: Range of dissolved oxygen values for inflow and outflow for all facilities (A.) and each facility (B.). 
Table 8: Summary table of inflow, outflow and percent reduction for conductivity, $\mathrm{pH}$ and dissolved oxygen.

\begin{tabular}{|c|c|c|c|c|c|c|c|c|c|}
\hline \multirow[b]{2}{*}{ Parameter } & \multicolumn{3}{|c|}{ In } & \multicolumn{3}{|c|}{ Out } & \multicolumn{3}{|c|}{ Percent Reduction } \\
\hline & Mean & SD & Median & Mean & SD & Median & $\begin{array}{c}\text { Percent } \\
\text { Reduction }\end{array}$ & $\begin{array}{l}\text { Lower } \\
\mathrm{Cl}\end{array}$ & $\begin{array}{c}\text { Upper } \\
\mathrm{Cl}\end{array}$ \\
\hline Conductivity (uS/cm) & 34.3 & 24.1 & 26.0 & 49.6 & 28.9 & 40.50 & $-52.2 \%$ & $-30.9 \%$ & $-75.1 \%$ \\
\hline $\mathrm{pH}$ & 6.9 & 0.5 & 6.9 & 6.5 & 0.4 & 6.40 & $5.8 \%$ & $3.9 \%$ & $6.8 \%$ \\
\hline $\begin{array}{l}\text { Dissolved Oxygen } \\
(\mathrm{mg} / \mathrm{L})\end{array}$ & 10.8 & 1.3 & 11.1 & 10.4 & 1.1 & 10.65 & $3.0 \%$ & $0.0 \%$ & $5.8 \%$ \\
\hline
\end{tabular}

Variability between Seasons

All models were first run with season included as a fixed effect with fall defined as September through November, winter as December through February and spring as March through May. A total of 10 observations were collected in fall and 21 in both winter and spring (see Table 2). However, all 10 samples in fall were collected in November, therefore the early months of fall (and potential first flush effects) are not represented by these samples. Due to the uneven representation of seasons and lack of early season sampling, we will not draw any conclusions from this data regarding variability by season. However, the following trends were observed based on the collected data.

For nutrients, no differences between seasons were observed for ammonia or orthophosphate but outflow values for nitrate were slightly lower in the winter and total P was lower in the fall. For all metals, samples were lower in the fall compared to 
winter and spring, although some differences may be negligible. No difference in TSS was observed based on season.

Inflow pollutant levels are expected to be higher in the fall due to higher plant debris inputs, dry periods between storms, and first flush effects. However, these effects were likely not captured by this study due to the lack of early season samples. Interestingly, total P and all metals were lower in the fall, showing the opposite trend. High pollen during the spring can contribute additional $\mathrm{N}$ and $\mathrm{P}$ in runoff (Brown et al., 2013). However, this trend was not clearly observed in this data.

As described in the introduction, seasons may also impact bioretention treatment effectiveness for some analytes. Most notably, nitrate leaching may increase at higher temperatures due to increased rates of nitrification and microbial activity (Blecken et al., 2010; Brown et al., 2013). The results for nitrate from this study show slightly lower nitrate levels during the winter, which is consistent with the expected temperature effect on nitrification.

\section{Other Considerations and Limitations}

The goal of this study was to assess bioretention effectiveness during real storm events, which limited our ability to control for all differences between storm events and facility characteristics. In regard to storm events, samples were taken at different points during a storm (i.e., some may have been collected at the beginning of the storm while others were collected at the peak or the tail of the storm event). Therefore, differences in rainfall amounts and rates, runoff intensity and antecedent conditions may affect the 
amount of pollutants in runoff. In addition, since grab samples were used, levels of pollutants may vary based on when the sample was collected within a specific storm event (i.e. levels may be higher with the first flush of runoff through the facility versus later in the storm event). In terms of facility variability, as described in Table 1 above, facilities vary based on the sizing ratio of the facility to its catchment area. Furthermore, the species and coverage of vegetation vary between facilities, which can potentially impact treatment effectiveness. All facilities receive runoff from public streets, however, the use intensity of the streets varies between facilities.

Another potential source of uncertainty is the unknown lag time between inflow and outflow of stormwater: the water collected flowing into the facility is not the exact water collected flowing out of the facility. Therefore, we are assuming that the grab samples are generally representative of the overall inflow and outflow from the facilities. Based on field observations, the lag time from inflow to outflow is likely in the range of minutes to hours, depending on the facility.

Another consideration worth a brief discussion is the use of percent removal as a measure of bioretention treatment effectiveness. Although commonly used in stormwater research, percent removal has some shortcomings. First, it is highly dependent on the influent water quality; more polluted influent water will often show higher percent removals compared to clean runoff (Wright Water Engineers and Geosyntec Consultants, 2007). In addition, since the facilities are all designed with overflow systems for runoff to bypass the facility during large storms, the percent 
reductions represent only the runoff that actually flowed through the bioretention facility. An important consideration in determining overall water quality treatment effectiveness of the facilities would be to determine what proportion of runoff bypasses the facility altogether.

Calculated percent removals represent changes in concentration and do not account for total load reductions of pollutants (Wright Water Engineers and Geosyntec Consultants, 2007). This is especially important to consider in unlined bioretention facilities that infiltrate stormwater into the ground and significantly reduce the total amount of runoff (and therefore pollutant load) delivered to the receiving system. The bioretention facilities measured in this study are lined; therefore, the amount of overall load reduction is likely minimal. Although we considered this limitation during study design, based on the location of the facilities along streets and the specific inlet and outlet configurations, it was not feasible to monitor total flow rate and volume for this study.

Despite these limitations, the results of this study still provide valuable insight into the in-field treatment effectiveness of established bioretention facilities in Portland, Oregon. In addition, sampling seven different facilities across multiple storm events provides important data illustrating variability between facilities and between storm events. 


\section{Conclusions}

Results of this study indicate that established bioretention facilities in Portland, Oregon are not effectively or uniformly decreasing the concentration of all forms of nutrients in stormwater runoff. For $\mathrm{N}$, concentrations of ammonia were very effectively decreased; however, the facilities increased the concentration of nitrate in effluent. For $\mathrm{P}$, moderate reduction in total $\mathrm{P}$ was observed; however, the facilities led to an increase in orthophosphate. For metals, results showed moderate to good removal of total $\mathrm{Cu}$, total $\mathrm{Zn}$ and dissolved $\mathrm{Zn}$. Overall, results for dissolved $\mathrm{Cu}$ indicated an increase in outflow levels from the bioretention facilities; however, observed results varied between facilities. Highly effective and consistent removal of TSS was observed for all sampled bioretention facilities. For other general water quality parameters, the bioretention facilities led to a slight increase in conductivity and a slight decrease in $\mathrm{pH}$ and dissolved oxygen.

Based on the results of this study, highly effective TSS removal by bioretention facilities does not necessarily equate to reduction of other pollutants of concern, especially nitrate and orthophosphate. Based on these observations, TSS is not an accurate surrogate measure for overall water quality improvement, especially for dissolved pollutants.

Considering the increased levels of orthophosphate and nitrate in effluent, the logical next question is whether the observed levels are high enough to negatively impact receiving waterbodies. However, there are no water quality criteria defined 
specifically for urban stormwater runoff. In addition, there are no defined instream water quality criteria for nitrate or orthophosphate in the Portland area (criteria exist for total P, which were used as a comparison for orthophosphate). Without these criteria, it is unclear whether the observed effluent levels are of significant concern; therefore, additional research and modeling may be an important next step. In addition, further research and testing of improved bioretention design to improve nitrate and orthophosphate removal is recommended.

Although this study looked at bioretention facilities that are past their establishment period, it did not focus specifically on any effect of facility age on treatment. However, the sampling completed in this study could be continued in future years to assess changes in pollution reduction effectiveness of the facilities as they age. This type of research appears to be lacking in the available literature, which focuses heavily on column studies and tests of newly installed facilities. 


\section{References}

American Public Health Association, 2005. Standard Methods for the Examination of Water \& Wastewater, 21st ed.

Azrina, M.Z., Yap, C.K., Rahim Ismail, A., Ismail, A., Tan, S.G., 2006. Anthropogenic impacts on the distribution and biodiversity of benthic macroinvertebrates and water quality of the Langat River, Peninsular Malaysia. Ecotoxicol. Environ. Saf. 64, 337-347. https://doi.org/10.1016/j.ecoenv.2005.04.003

Baldwin, D.H., Sandahl, J.F., Labenia, J.S., Scholz, N.L., 2003. Sublethal effects of copper on coho salmon: Impacts on nonoverlapping receptor pathways in the peripheral olfactory nervous system. Environ. Toxicol. Chem. 22, 2266-2274. https://doi.org/10.1897/02-428

Barbosa, A.E., Fernandes, J.N., David, L.M., 2012. Key issues for sustainable urban stormwater management. Water Res., Special Issue on Stormwater in urban areas 46, 6787-6798. https://doi.org/10.1016/j.watres.2012.05.029

Bettez, N.D., Groffman, P.M., 2013. Nitrogen Deposition in and near an Urban Ecosystem. Environ. Sci. Technol. 47, 6047-6051. https://doi.org/10.1021/es400664b

Blecken, G.-T., Zinger, Y., Deletić, A., Fletcher, T.D., Hedström, A., Viklander, M., 2010. Laboratory study on stormwater biofiltration: Nutrient and sediment removal in cold temperatures. J. Hydrol. 394, 507-514. https://doi.org/10.1016/j.jhydrol.2010.10.010

Bonneau, J., Fletcher, T.D., Costelloe, J.F., Burns, M.J., 2017. Stormwater infiltration and the 'urban karst' - A review. J. Hydrol. 552, 141-150. https://doi.org/10.1016/j.jhydrol.2017.06.043

Bratieres, K., Fletcher, T.D., Deletic, A., Zinger, Y., 2008. Nutrient and sediment removal by stormwater biofilters: a large-scale design optimisation study. Water Res. 42, 3930-3940. https://doi.org/10.1016/j.watres.2008.06.009

Brinkman, S.F., Johnston, W.D., 2007. Acute Toxicity of Aqueous Copper, Cadmium, and Zinc to the Mayfly Rhithrogena hageni. Arch. Environ. Contam. Toxicol. 54, 466. https://doi.org/10.1007/s00244-007-9043-z

Brown, R.A., Birgand, F., Hunt, W.F., 2013. Analysis of Consecutive Events for Nutrient and Sediment Treatment in Field-Monitored Bioretention Cells. Water. Air. Soil Pollut. 224, 1581. https://doi.org/10.1007/s11270-013-1581-6

Brown, R.A., Hunt, W.F., 2011. Underdrain Configuration to Enhance Bioretention Exfiltration to Reduce Pollutant Loads. J. Environ. Eng. 137, 1082-1091. https://doi.org/10.1061/(ASCE)EE.1943-7870.0000437

Bureau of Environmental Services, 2016. City of Portland Stormwater Management Manual.

Bürkner, P.-C., 2016. brms: An R Package for Bayesian Multilevel Models Using Stan. Journal of Statistical Software, 80(1), 1-28. 
Burton, D.T., Jones, A.H., Cairns Jr., J., 1972. Acute Zinc Toxicity to Rainbow Trout (Salmo gairdneri): Confirmation of the Hypothesis that Death is Related to Tissue Hypoxia. J. Fish. Res. Board Can. 29, 1463-1466. https://doi.org/10.1139/f72-225

Capper, N., 2006. The Effects of Suspended Sediment on the Aquatic Organisms Daphnia magna and Pimephales promelas. Clemson Univ. Theses.

Carpenter, S.R., Caraco, N.F., Correll, D.L., Howarth, R.W., Sharpley, A.N., Smith, V.H., 1998. Nonpoint Pollution of Surface Waters with Phosphorus and Nitrogen. Ecol. Appl. 8, 559-568. https://doi.org/10.1890/10510761(1998)008[0559:NPOSWW]2.0.CO;2

Chahal, M.K., Shi, Z., Flury, M., 2016. Nutrient leaching and copper speciation in compost-amended bioretention systems. Sci. Total Environ. 556, 302-309. https://doi.org/10.1016/j.scitotenv.2016.02.125

City of Portland, 2019. Blended Soil Specification for Vegetated Stormwater Systems.

City of Portland, Port of Portland, 2018. Annual Compliance Report No. 23, National Pollutant Discharge Elimination System (NPDES) Municipal Separate Storm Sewer System (MS4) Discharge Permit No. 101314.

Clar, M., Barfield, B.J., O'Connor, T., 2004. Stormwater Best Management Practices Design Guide Volume 1 - General Considerations (No. EPA/600/R-04/121). U.S. Environmental Protection Agency, Washington, DC.

Clements, W.H., Cherry, D.S., Cairns, J., 1988. Structural alterations in aquatic insect communities exposed to copper in laboratory streams. Environ. Toxicol. Chem. 7, 715-722. https://doi.org/10.1002/etc.5620070905

Coles, J.F., McMahon, G., Bell, A.H., Brown, L.R., Fitzpatrick, F.A., Scudder Eikenberry, B.C., Woodside, M.D., Cuffney, T.F., Bryant Jr., W.L., Cappiella, K., Fraley-McNeal, L., Stack, W.P., 2012. Effects of urban development on stream ecosystems in nine metropolitan study areas across the United States (USGS Numbered Series No. 1373), Circular. U.S. Geological Survey, Reston, VA.

Collins, K.A., Lawrence, T.J., Stander, E.K., Jontos, R.J., Kaushal, S.S., Newcomer, T.A., Grimm, N.B., Cole Ekberg, M.L., 2010. Opportunities and challenges for managing nitrogen in urban stormwater: A review and synthesis. Ecol. Eng., Managing Denitrification in Human Dominated Landscapes 36, 1507-1519. https://doi.org/10.1016/j.ecoleng.2010.03.015

Compton, J.E., Harrison, J.A., Dennis, R.L., Greaver, T.L., Hill, B.H., Jordan, S.J., Walker, H., Campbell, H.V., 2011. Ecosystem services altered by human changes in the nitrogen cycle: a new perspective for US decision making. Ecol. Lett. 14, 804815. https://doi.org/10.1111/j.1461-0248.2011.01631.x

Correll, D.L., 1998. The role of phosphorus in the eutrophication of receiving waters: A review. J. Environ. Qual. Madison 27, 261.

Courtney, L.A., Clements, W.H., 1998. Effects of acidic pH on benthic macroinvertebrate communities in stream microcosms. Hydrobiologia 379, 135-145.

https://doi.org/10.1023/A:1003442013650 
Cusimano, R.F., Brakke, D.F., Chapman, G.A., 1986. Effects of pH on the Toxicities of Cadmium, Copper, and Zinc to Steelhead Trout (Salmo gairdneri). Can. J. Fish. Aquat. Sci. 43, 1497-1503. https://doi.org/10.1139/f86-187

Davidson, E.A., Savage, K.E., Bettez, N.D., Marino, R., Howarth, R.W., 2010. Nitrogen in Runoff from Residential Roads in a Coastal Area. Water. Air. Soil Pollut. 210, 313. https://doi.org/10.1007/s11270-009-0218-2

Davis, A.P., Hunt, W.F., Traver, R.G., Clar, M., 2009. Bioretention Technology: Overview of Current Practice and Future Needs. J. Environ. Eng. 135, 109-117. https://doi.org/10.1061/(ASCE)0733-9372(2009)135:3(109)

Davis, A.P., Shokouhian, M., Ni, S., 2001a. Loading estimates of lead, copper, cadmium, and zinc in urban runoff from specific sources. Chemosphere 44, 997-1009. https://doi.org/10.1016/S0045-6535(00)00561-0

Davis, A.P., Shokouhian, M., Sharma, H., Minami, C., 2006. Water Quality Improvement through Bioretention Media: Nitrogen and Phosphorus Removal. Water Environ. Res. 78, 284-293.

Davis, A.P., Shokouhian, M., Sharma, H., Minami, C., 2001b. Laboratory Study of Biological Retention for Urban Stormwater Management. Water Environ. Res. 73, 5-14. https://doi.org/10.2175/106143001X138624

Dietz, M.E., Clausen, J.C., 2006. Saturation to Improve Pollutant Retention in a Rain Garden. Environ. Sci. Technol. 40, 1335-1340. https://doi.org/10.1021/es051644f

Elliott, H.A., Liberati, M.R., Huang, C.P., 1986. Competitive Adsorption of Heavy Metals by Soils 1. J. Environ. Qual. 15, 214-219. https://doi.org/10.2134/jeq1986.00472425001500030002x

Erickson, A.J., Gulliver, J.S., Weiss, P.T., 2007. Enhanced Sand Filtration for Storm Water Phosphorus Removal. J. Environ. Eng. 133, 485-497. https://doi.org/10.1061/(ASCE)0733-9372(2007)133:5(485)

Grosell, M., 2011. 2 - Copper, in: Wood, C.M., Farrell, A.P., Brauner, C.J. (Eds.), Fish Physiology, Homeostasis and Toxicology of Essential Metals. Academic Press, pp. 53-133. https://doi.org/10.1016/S1546-5098(11)31002-3

Harrison, X.A., Donaldson, L., Correa-Cano, M.E., Evans, J., Fisher, D.N., Goodwin, C.E.D., Robinson, B.S., Hodgson, D.J., Inger, R., 2018. A brief introduction to mixed effects modelling and multi-model inference in ecology. PeerJ 6. https://doi.org/10.7717/peerj.4794

Hatt, B.E., Fletcher, T.D., Deletic, A., 2009. Hydrologic and pollutant removal performance of stormwater biofiltration systems at the field scale. J. Hydrol. 365, 310-321. https://doi.org/10.1016/j.jhydrol.2008.12.001

Herrera Environmental Consultants, Inc., 2014. Final Report: 185th Avenue NE Bioretention Stormwater Treatment System Performance Monitoring.

Hogstrand, C., 2011. 3 - Zinc, in: Wood, C.M., Farrell, A.P., Brauner, C.J. (Eds.), Fish Physiology, Homeostasis and Toxicology of Essential Metals. Academic Press, pp. 135-200. https://doi.org/10.1016/S1546-5098(11)31003-5 
Hopkinson, C.S., Giblin, A.E., 2008. Chapter 22 - Nitrogen Dynamics of Coastal Salt Marshes, in: Capone, D.G., Bronk, D.A., Mulholland, M.R., Carpenter, E.J. (Eds.), Nitrogen in the Marine Environment (Second Edition). Academic Press, San Diego, pp. 991-1036. https://doi.org/10.1016/B978-0-12-372522-6.00022-0

Hsieh, C., Davis, A.P., 2005. Evaluation and Optimization of Bioretention Media for Treatment of Urban Storm Water Runoff. J. Environ. Eng. 131, 1521-1531. https://doi.org/10.1061/(ASCE)0733-9372(2005)131:11(1521)

Hsieh, C., Davis, A.P., Needelman, B.A., 2007a. Bioretention Column Studies of Phosphorus Removal from Urban Stormwater Runoff. Water Environ. Res. 79, 177-184.

Hsieh, C., Davis, A.P., Needelman, B.A., 2007b. Nitrogen Removal from Urban Stormwater Runoff Through Layered Bioretention Columns. Water Environ. Res. 79, 2404-2411. https://doi.org/10.2175/106143007X183844

Hunt, W.F., Davis, A.P., Traver, R.G., 2012. Meeting Hydrologic and Water Quality Goals through Targeted Bioretention Design. J. Environ. Eng. 138, 698-707. https://doi.org/10.1061/(ASCE)EE.1943-7870.0000504

Hunt, W.F., Jarrett, A.R., Smith, J.T., Sharkey, L.J., 2006. Evaluating Bioretention Hydrology and Nutrient Removal at Three Field Sites in North Carolina. J. Irrig. Drain. Eng. 132, 600-608. https://doi.org/10.1061/(ASCE)07339437(2006)132:6(600)

Jang, A., Seo, Y., Bishop, P.L., 2005. The removal of heavy metals in urban runoff by sorption on mulch. Environ. Pollut. 133, 117-127. https://doi.org/10.1016/j.envpol.2004.05.020

Janke, B.D., Finlay, J.C., Hobbie, S.E., Baker, L.A., Sterner, R.W., Nidzgorski, D., Wilson, B.N., 2014. Contrasting influences of stormflow and baseflow pathways on nitrogen and phosphorus export from an urban watershed. Biogeochemistry 121, 209-228. https://doi.org/10.1007/s10533-013-9926-1

Kim, H., Seagren, E.A., Davis, A.P., 2003. Engineered Bioretention for Removal of Nitrate from Stormwater Runoff. Water Environ. Res. 75, 355-367. https://doi.org/10.2175/106143003X141169

Kjelland, M.E., Woodley, C.M., Swannack, T.M., Smith, D.L., 2015. A review of the potential effects of suspended sediment on fishes: potential dredging-related physiological, behavioral, and transgenerational implications. Environ. Syst. Decis. 35, 334-350. https://doi.org/10.1007/s10669-015-9557-2

Law, N., Band, L., Grove, M., 2004. Nitrogen input from residential lawn care practices in suburban watersheds in Baltimore county, MD. J. Environ. Plan. Manag. 47, 737755. https://doi.org/10.1080/0964056042000274452

LeFevre, G.H., Paus, K.H., Natarajan, P., Gulliver, J.S., Novak, P.J., Hozalski, R.M., 2015. Review of Dissolved Pollutants in Urban Storm Water and Their Removal and Fate in Bioretention Cells. J. Environ. Eng. 141, 04014050. https://doi.org/10.1061/(ASCE)EE.1943-7870.0000876 
Li, H., Davis, A.P., 2008. Heavy Metal Capture and Accumulation in Bioretention Media. Environ. Sci. Technol. 42, 5247-5253. https://doi.org/10.1021/es702681j

Li, J., Davis, A.P., 2016. A unified look at phosphorus treatment using bioretention. Water Res. 90, 141-155. https://doi.org/10.1016/j.watres.2015.12.015

Linbo, T.L., Baldwin, D.H., McIntyre, J.K., Scholz, N.L., 2009. Effects of water hardness, alkalinity, and dissolved organic carbon on the toxicity of copper to the lateral line of developing fish. Environ. Toxicol. Chem. 28, 1455.

https://doi.org/10.1897/08-283.1

Liu, J., Davis, A.P., 2014. Phosphorus Speciation and Treatment Using Enhanced Phosphorus Removal Bioretention. Environ. Sci. Technol. 48, 607-614. https://doi.org/10.1021/es404022b

Liu, J., Sample, D.J., Bell, C., Guan, Y., 2014. Review and Research Needs of Bioretention Used for the Treatment of Urban Stormwater. Water 6, 1069-1099. http://dx.doi.org.proxy.lib.pdx.edu/10.3390/w6041069

Lucas, W.C., Greenway, M., 2011. Phosphorus Retention by Bioretention Mesocosms Using Media Formulated for Phosphorus Sorption: Response to Accelerated Loads. J. Irrig. Drain. Eng. 137, 144-153. https://doi.org/10.1061/(ASCE)IR.19434774.0000243

McGrane, S.J., 2016. Impacts of urbanisation on hydrological and water quality dynamics, and urban water management: a review. Hydrol. Sci. J. 61, 2295-2311. https://doi.org/10.1080/02626667.2015.1128084

McIntyre, J.K., Baldwin, D.H., Meador, J.P., Scholz, N.L., 2008. Chemosensory Deprivation in Juvenile Coho Salmon Exposed to Dissolved Copper under Varying Water Chemistry Conditions. Environ. Sci. Technol. 42, 1352-1358. https://doi.org/10.1021/es071603e

McRae, N.K., Gaw, S., Glover, C.N., 2016. Mechanisms of zinc toxicity in the galaxiid fish, Galaxias maculatus. Comp. Biochem. Physiol. Part C Toxicol. Pharmacol. 179, 184-190. https://doi.org/10.1016/j.cbpc.2015.10.010

Mebane, C.A., Dillon, F.S., Hennessy, D.P., 2012. Acute toxicity of cadmium, lead, zinc, and their mixtures to stream-resident fish and invertebrates. Environ. Toxicol.

Chem. 31, 1334-1348. https://doi.org/10.1002/etc.1820

Minero, C., Chiron, S., Falletti, G., Maurino, V., Pelizzetti, E., Ajassa, R., Carlotti, M.E., Vione, D., 2007. Photochemincal processes involving nitrite in surface water samples. Aquat. Sci. 69, 71-85. https://doi.org/10.1007/s00027-007-0881-6

Minton, G., 2005. Stormwater Treatment: Biological, Chemical \& Engineering Principles. Sheridan Books, Inc.

Morgan, J.G., Paus, K.A., Hozalski, R.M., Gulliver, J.S., 2011. Sorption and release of dissolved pollutants via bioretention media. (No. Project Report 559). University of Minnesota St. Anthony Falls Laboratory.

Mullane, J.M., Flury, M., Iqbal, H., Freeze, P.M., Hinman, C., Cogger, C.G., Shi, Z., 2015. Intermittent rainstorms cause pulses of nitrogen, phosphorus, and copper in 
leachate from compost in bioretention systems. Sci. Total Environ. 537, 294-303. https://doi.org/10.1016/j.scitotenv.2015.07.157

Muthanna, T.M., Viklander, M., Gjesdahl, N., Thorolfsson, S.T., 2007. Heavy Metal Removal in Cold Climate Bioretention. Water. Air. Soil Pollut. 183, 391-402. https://doi.org/10.1007/s11270-007-9387-z

Nason, J.A., Sprick, M.S., Bloomquist, D.J., 2012. Determination of copper speciation in highway stormwater runoff using competitive ligand exchange - Adsorptive cathodic stripping voltammetry. Water Res. 46, 5788-5798. https://doi.org/10.1016/j.watres.2012.08.008

O'Neill, S.W., Davis, A.P., 2012. Water Treatment Residual as a Bioretention Amendment for Phosphorus. I: Evaluation Studies. J. Environ. Eng. 138, 318-327. https://doi.org/10.1061/(ASCE)EE.1943-7870.0000409

OR DEQ, 2011. National Pollutant Discharge Elimination System Municipal Separate Storm Sewer System (MS4) Discharge Permit.

Oregon DEQ, 2017. National Pollutant Discharge Elimination System Stormwater Discharge General Permit No. 1200-Z.

Oregon DEQ, 2012. Tualatin Subbasin Total Maximum Daily Load (TMDL).

Oregon DEQ, 2004. Oregon Administrative Rules, Chapter 430, Division 041, Water Quality Standards: Beneficial Uses, Policies, and Criteria for Oregon.

Oregon DEQ, 1998. Columbia Slough Total Maximum Daily Loads (TMDL).

Passeport, E., Hunt, W.F., Line, D., Smith, R.A., Brown, R., 2009. Field Study of the Ability of Two Grassed Bioretention Cells to Reduce StormWater Runoff Pollution. J. Irrig. Drain. Eng. 135. https://doi.org/10.1061/(ASCE)IR.1943-4774.0000006

Paul, M.J., Meyer, J.L., 2001. Streams in the Urban Landscape. Annu. Rev. Ecol. Syst. 32, 333-365. https://doi.org/10.1146/annurev.ecolsys.32.081501.114040

Paus, K.H., Morgan, J., Gulliver, J.S., Hozalski, R.M., 2014. Effects of Bioretention Media Compost Volume Fraction on Toxic Metals Removal, Hydraulic Conductivity, and Phosphorous Release. J. Environ. Eng. 140, 04014033. https://doi.org/10.1061/(ASCE)EE.1943-7870.0000846

Peterson, I.J., Igielski, S., Davis, A.P., 2015. Enhanced Denitrification in Bioretention Using Woodchips as an Organic Carbon Source. J. Sustain. Water Built Environ. 1, 04015004. https://doi.org/10.1061/JSWBAY.0000800

Poor, C.J., Conkle, K., MacDonald, A., Duncan, K., 2018. Water Treatment Residuals in Bioretention Planters to Reduce Phosphorus Levels in Stormwater. Environ. Eng. Sci. 36, 265-272. https://doi.org/10.1089/ees.2018.0254

$\mathrm{R}$ Core Team, 2018. R: A language and environment for statistical computing. $\mathrm{R}$ Foundation for Statistical Computing, Vienna, Austria.

Read, J., Wevill, T., Fletcher, T., Deletic, A., 2008. Variation among plant species in pollutant removal from stormwater in biofiltration systems. Water Res. 42, 893902. https://doi.org/10.1016/j.watres.2007.08.036

Rosenquist, S.E., Hession, W.C., Eick, M.J., Vaughan, D.H., 2010. Variability in adsorptive phosphorus removal by structural stormwater best management practices. Ecol. 
Eng., Carbon, nutrient and metal retention in wetlands in a restoration context 36, 664-671. https://doi.org/10.1016/j.ecoleng.2009.12.008

Roy-Poirier, A., Champagne, P., Filion, 2010a. Review of Bioretention System Research and Design: Past, Present, and Future. J. Environ. Eng. 136, 878-889. https://doi.org/10.1061/(ASCE)EE.1943-7870.0000227

Roy-Poirier, A., Champagne, P., Filion, Y., 2010b. Bioretention processes for phosphorus pollution control. Environ. Rev. 18, 159-173. https://doi.org/10.1139/A10-006

Sandahl, J.F., Baldwin, D.H., Jenkins, J.J., Scholz, N.L., 2007. A Sensory System at the Interface between Urban Stormwater Runoff and Salmon Survival. Environ. Sci. Technol. 41, 2998-3004. https://doi.org/10.1021/es062287r

Santore, R.C., Toro, D.M.D., Paquin, P.R., Allen, H.E., Meyer, J.S., 2001. Biotic ligand model of the acute toxicity of metals. 2. Application to acute copper toxicity in freshwater fish and Daphnia. Environ. Toxicol. Chem. 20, 2397-2402. https://doi.org/10.1002/etc.5620201035

Sawyer, C.N., McCarty, P.L., Parkin, G.F., 2002. Chemistry for Environmental Engineering and Science, 5th ed, McGraw-Hill Series in Civil and Environmental Engineering. McGraw-Hill Education.

Scannell, P.W., 2009. Effects of Copper on Aquatic Species: A review of the literature (No. Technical Report No 09-04). Alaska Department of Fish and Game.

Schlesinger, W.H., Bernhardt, E.S., 2013. Biogeochemistry, 3rd ed. Elsevier.

Schoellhamer, D.H., Mumley, T.E., Leatherbarrow, J.E., 2007. Suspended sediment and sediment-associated contaminants in San Francisco Bay. Environ. Res., Pollutants in the San Francisco Bay Estuary 105, 119-131. https://doi.org/10.1016/j.envres.2007.02.002

Shetterly, B.J., 2018. Soil Phosphorus Characterization and Vulnerability to Release in Urban Stormwater Bioretention Facilities. Portland State University Dissertations and Theses.

Solomon, F., 2009. Impacts of Copper on Aquatic Ecosystems and Human Health. Environ. Communities.

Sun, X., Davis, A.P., 2007. Heavy metal fates in laboratory bioretention systems. Chemosphere 66, 1601-1609. https://doi.org/10.1016/j.chemosphere.2006.08.013

Taylor, K.G., Owens, P.N., 2009. Sediments in urban river basins: a review of sedimentcontaminant dynamics in an environmental system conditioned by human activities. J. Soils Sediments 9, 281-303. https://doi.org/10.1007/s11368-0090103-z

Trowsdale, S.A., Simcock, R., 2011. Urban stormwater treatment using bioretention. J. Hydrol. 397, 167-174. https://doi.org/10.1016/j.jhydrol.2010.11.023

US EPA, 2016. Biotic Ligand Model and Copper Criteria.

US EPA, 2009. National Primary Drinking Water Regulations.

US EPA, 1999. Preliminary Data Summary of Urban Stormwater Water Best Management Practices (No. EPA-821-R-99-012). 
US EPA, 1994. Method 200.8, Revision 5.4: Determination of Trace Elements in Waters and Wasts by Inductively Couped Plasma - Mass Spectrometry.

US EPA, 1993a. Method 353.2, Revision 2.0: Determination of Nitrate-Nitrite Nitrogen by Automated Colorimetry.

US EPA, 1993b. Method 300.0, Determination of Inorganic Anions by lon Chromatography.

US EPA, 1993c. Method 350.1, Determination of Ammonia Nitrogen by Semi-Automated Colorimetry.

US EPA, 1993d. Method 365.1, Revision 2.0: Determination of Phosphorus by SemiAutomated Colorimetry.

US EPA, 1980. Ambient Water Quality Criteria for Zinc (No. EPA 440/5-80-079).

USGS, n.d. Surface Water data for USA.

Walker, C.H., Sibly, R.M., Hopkin, S.P., Peakall, D.B., 2012. Principles of Ecotoxicology, 4th ed. CRC Press.

Walsh, C.J., Booth, D.B., Burns, M.J., Fletcher, T.D., Hale, R.L., Hoang, L.N., Livingston, G., Rippy, M.A., Roy, A.H., Scoggins, M., Wallace, A., 2016. Principles for urban stormwater management to protect stream ecosystems. Freshw. Sci. 35, 398411. https://doi.org/10.1086/685284

Walsh, C.J., Roy, A.H., Feminella, J.W., Cottingham, P.D., Groffman, P.M., Morgan, R.P., 2005. The urban stream syndrome: current knowledge and the search for a cure. J. North Am. Benthol. Soc. 24, 706-723. https://doi.org/10.1899/04-028.1

WHO, 2001. Environmental Health Criteria 221: Zinc. World Health Organization.

Wright Water Engineers, Geosyntec Consultants, 2007. Frequently Asked Questions Fact Sheet for the International Stormwater BMP Database: Why does the International Stormwater BMP Database Project omit percent removal as a measure of BMP performance?

Yang, Y.-Y., Lusk, M.G., 2018. Nutrients in Urban Stormwater Runoff: Current State of the Science and Potential Mitigation Options. Curr. Pollut. Rep. 4, 112-127. https://doi.org/10.1007/s40726-018-0087-7

Yang, Y.-Y., Toor, G.S., 2016. $\delta 15 \mathrm{~N}$ and $\delta 180$ Reveal the Sources of Nitrate-Nitrogen in Urban Residential Stormwater Runoff. Environ. Sci. Technol. 50, 2881-2889. https://doi.org/10.1021/acs.est.5b05353

Zhang, W., Brown, G.O., Storm, D.E., Zhang, H., 2008. Fly-ash-amended sand as filter media in bioretention cells to improve phosphorus removal. Water Environ. Res. 80, 507-516. 